\title{
Just how multi-level is leadership research? A document co-citation analysis 1980-2013 on leadership constructs and outcomes
}

Article

Accepted Version

Creative Commons: Attribution-Noncommercial-No Derivative Works 4.0

Batistic, S., Cerne, M. and Vogel, B. (2017) Just how multilevel is leadership research? A document co-citation analysis 1980-2013 on leadership constructs and outcomes. The Leadership Quarterly, 28 (1). pp. 86-103. ISSN 1048-9843 doi: https://doi.org/10.1016/j.leaqua.2016.10.007 Available at https://centaur.reading.ac.uk/67378/

It is advisable to refer to the publisher's version if you intend to cite from the work. See Guidance on citing.

To link to this article DOI: http://dx.doi.org/10.1016/j.leaqua.2016.10.007

Publisher: Elsevier

All outputs in CentAUR are protected by Intellectual Property Rights law, including copyright law. Copyright and IPR is retained by the creators or other copyright holders. Terms and conditions for use of this material are defined in the End User Agreement. 


\section{CentAUR}

Central Archive at the University of Reading

Reading's research outputs online 


\title{
Just how multi-level is leadership research? A document co-citation analysis 1980-2013 on leadership constructs and outcomes
}

\begin{abstract}
The use of multi-level theories and methodologies in leadership has gained momentum in recent years. However, the leadership field still suffers from a fragmented and unclear evolution and practice of multi-level approaches. The questions of how and to what extent multi-level research has evolved in both leadership phenomena and leadership outcomes, and which informal research networks drove this evolution, remain vastly unexplored. In this study, the extent of literature published between 1980 and 2013 is analyzed using a document co-citation analysis and invisible colleges' framework. This allows us to map the evolution of the multi-level intellectual structure of the leadership field. Specifically, we identify a number of distinct colleges -their conceptualization of leadership and outcomes - and trace their evolution paths over thirty years. We find a considerable fragmentation of the field, with the usage of multi-level leadership conceptualization mostly embraced by more peripheral clusters. Finally we discuss implications for further research with regard to a set of distinct trajectories for the future evolution of multi-level approaches in the leadership domain.
\end{abstract}

Keywords: leadership, outcomes, multilevel, review, co-citation analysis 


\section{Introduction}

"Understand the whole and keep an eye on the parts.” (Kozlowski \& Klein, 2000, p. 53)

In the last two decades, multi-level management studies (Eggers \& Kaplan, 2013) have surged in numbers and the multi-level paradigm has permeated virtually every sub-discipline of management (Mathieu \& Chen, 2011). Leadership researchers have also increasingly adopted a multi-level approach, focusing on multi-level theory and multi-level data analytical techniques (Hsiung, 2012; Markham, 2010; Olsson, Hemlin, \& Pousette, 2012; Yammarino \& Dansereau, 2011). With this scholars aim for an understanding of how leadership and its outcomes unfold within and across different levels of organizations (Kozlowski \& Klein, 2000). This research focus likewise represents practical leadership challenges in organizations, such as goal-setting, alignment, adaptation, efficiency or effectiveness, which typically involves simultaneously various analytical levels in organizations (e.g. individuals, groups or units) and includes bottom-up emergence or top-down cascading (Chen, Mathieu, \& Bliese, 2004). Therefore, multi-level studies about leadership as a phenomenon and the outcomes of leadership can offer greater theoretical progress, predictive power and real-world relevance (Bamberger, 2008).

Nevertheless, the leadership field shows fragmented theorizing and application of multi-level thinking and therefore exhibits an inconsistent evolution of multi-level approaches (Yammarino, Dionne, Uk Chun, \& Dansereau, 2005). The majority of leadership research shows only scant theorizing and operationalizing of multi-level frameworks (Liden, Wayne, Zhao, \& Henderson, 2008; Schriesheim, Wu, \& Scandura, 2009; Taggar \& Ellis, 2007). In recent years, substantial attempts have been made to surface the foundations underpinning multi-level studies in leadership with a focus on the quality and quantity of multi-level studies over time (e.g. Dionne et al., 2014; Tseng, Tung, \& Duan, 2010). When 
looking at these studies' findings, limitations emerge as they focus only on specific themes, (e.g. transformational leadership (Dionne et al., 2012)), concentrate on a set of high impact mainstream journals (DeChurch, Hiller, Murase, Doty, \& Salas, 2010) or one focal journal, The Leadership Quarterly (Dionne et al., 2014; Markham, 2010) where the predominance of leadership research was published. Questions of how and to what extent multi-level research into the leadership phenomenon and leadership outcomes started to appear, yet how this has evolved over time and which informal research networks or streams, invisible colleges (Vogel, 2012), drove this evolution, remain vastly unexplored despite leadership being, by definition, multi-level in nature.

Therefore, leadership research still lacks some conceptual and methodological clarity regarding the application of the multi-level paradigm. More importantly it further neglects a comprehensive and consistent understanding of the developmental patterns for the multi-level approach to leadership based on an all-encompassing body of leadership literature. This can limit the evaluation of progress in the domain and may hinder the identification of possible areas of future research in multi-level leadership studies. Instead review studies need to include a wide range of publications, such as books, book chapters or less-established journals with a broader thematic range in order to explore the intellectual structure and evolution of the multi-level nature of leadership, and to identify future avenues for research.

The present study aims to cast a dynamic perspective on the underlying structure and invisible colleges of multi-level approaches to leadership research with the main goal of uncovering specific paths and areas of future development that can advance the multi-level aspect in the leadership field, both overall and in distinct sub-domains. As invisible colleges can be defined as communications amongst scholars (in dyads or groups) who share interest in a particular area (de Solla Price, 1965), exploring such scholarly communication allow us to map the evolution of the intellectual structure of the leadership field over the last $30+$ 
years. It also allows us to examine longitudinal trajectories of leadership field evolution, not only for the levels involved in conceptualizing the leadership phenomenon (e.g. leadership styles, types, approaches etc.), but also, recognizing the extensive interest in the utility of leadership, i.e., at what level leadership outcomes (i.e. results, consequences) were most frequently studied. We base our study on a document co-citation analysis, a bibliometric technique that constructs measures of similarity between documents and is defined as the frequency with which two units are cited together (Small, 1973). Using this technique enables us to identify the most influential topics, the levels of analysis that they focus on predominantly, the extent to which specific colleges embrace a multi-level approach, and how they are connected with each other in communication networks. In this way, we can uncover a college's level of sophistication in theorizing and testing multi-level phenomena, on the nature of leadership and its outcomes, which also serves as a basis for offering prospects for the further development of the field.

In taking this approach, this study aims to contribute to the leadership literature in two ways. First, using a document co-citation approach adds to understanding the underlying structure and evolution of multi-level phenomena in the leadership field by offering a more comprehensive, inclusive and objective review study (Nerur, Rasheed, \& Natarajan, 2008; Vogel \& Güttel, 2013; Zupic \& Čater, 2015). Document co-citation analysis complements and expands other qualitative and meta-analytical reviews, effectively capturing the whole leadership field and building on a much bigger sample size of documents and thus allows us to also explore more marginal topics discovered within the leadership literature. Second, by drawing on college theory (Vogel, 2012) and building on network analysis rooted in a document co-citation approach, this study aims to expand the theorizing about the evolution of multi-level phenomena in leadership (Liden et al., 2008; Schriesheim et al., 2009; Taggar \& Ellis, 2007) and to subsequently propose developmental areas for the future evolution of 
the field. These are informed speculations (Vogel, 2012) about how multi-level approaches could possibly advance the leadership field in the existing dominant domains, in the emerging domains, as well as in the field in general. This has the potential to change our conversation within the field towards improving theorizing and empirical research in the colleges that have not yet fully embraced the multi-level approach, as well as to provide specific directions for potential additional connections with clusters that have.

\section{Leadership and levels approach: Towards multi-level research in}

\section{leadership}

Leadership is by nature a phenomenon that involves multiple conceptual levels because it can occur, for instance, between an individual leader and individual followers, groups of followers and/or entire organizations (Dionne et al., 2012) and can also cause organizationally relevant consequences at various levels. Multi-level approaches and challenges that address defining constructs, operationalizing of measures, and empirical tests of theoretical relationships are not new in the leadership field (Yammarino et al., 2005) and still remain current (Dionne et al., 2012). However, addressing an appropriate level of analysis and focusing on separate analytical levels may not be the only way to account for leadership phenomena and their outcomes at different levels. A multi-level approach that accounts for multiple levels of leadership occurrences and its outcomes simultaneously, and examines the cross-level interplay of the examined constructs (be it bottom-up/emergent or top-down), represents a step further (Dinh et al., 2014). With the start of the new millennium leadership research has collectively realized the need for combining multi-level theory and data analytical techniques, and the application of multi-level methods, techniques and analyses has improved (Markham, 2010). 
To establish the underlying structure and assess the quality of multi-level thinking in leadership, reviews and overview studies often consider entire leadership theories in a holistic manner and include their relation to multi-level lenses of theorizing or measurement (Yammarino \& Dansereau, 2011). This is understandable because leadership theories also develop their utility with their breadth and gestalt and leadership processes may initially or over time include recursive relationships between leadership occurrence and leadership outcomes (Gupta, Huang, \& Niranjan, 2010; Hunter, Bedell-Avers, \& Mumford, 2007).

However, to uncover the implicit structure and evolution of the multi-level approach in the leadership domain and to prevent monolithic categorization of leadership theories, the present study distinguishes between two areas. First, the occurrence of leadership addresses the level at which authors suggest the leadership phenomenon occurs. Within a leadership theory, addressing the occurrence of leadership is concerned with the question of where the leadership phenomenon stems from (Hernandez, Eberly, Avolio, \& Johnson, 2011). A second perspective is to consider the outcomes of leadership separately. From a multi-level perspective this lens is concerned with the classification of the levels at which the impact of leadership materializes at. We might find consistency regarding the uptake of multi-level approaches across leadership occurrence and leadership outcomes. However, there might also be differentiation between the two lenses since, for instance, in cross-level studies one typical emerging theoretical and empirical conceptualization primarily considers a multi-level approach for leadership outcomes only.

Furthermore, multi-level research in leadership remains fragmented and scattered across specific domains, which may be central to the predominant literature of leadership or relatively unconnected to each other (Yammarino et al., 2005). A review study of Dionne et al. (2014) revealed that both conceptual and empirical articles only explicitly state the focal level of analysis in approximately one-third of the articles, and that multi-level data analysis 
techniques are used in less than one-fifth of all articles published in The Leadership Quarterly in the last 25 years. We also witness numerous studies discussing the same topic at different levels, but with little recognition towards accounting for multi-level relationships or implications. Thus, multi-level theorizing and research in leadership remains disjointed (Hunt \& Dodge, 2000; Zaccaro, Rittman, \& Marks, 2002) with a risk that only specific domains embrace a multi-level approach.

This disconnect and fragmentation can be a result of the communications amongst scholars who share an interest in a particular area of leadership research - referred to as invisible colleges (de Solla Price, 1965). These colleges can be explored both in terms of "who" communicates and "how" they communicate. As noted by Crane (1972) usage of certain methods and theories in a field is driven by a small cluster of prominent scholars (the "who"). However, referring only to a few highly involved scholars is problematic, and a thorough examination of the field needs to include peripheral members who are indirectly linked to each other through their teachers and leaders - building a mirror image of the field. Given the importance of formal publications (the "how") for the evaluation and distribution of scientific knowledge and the allocation of professional recognition (Hagstrom, 1965), it may be possible to track the phenomena of invisible colleges in the publication system (Vogel, 2012). Yet, little research has been done to understand the intellectual roots of the multi-level conceptualization of leadership and its outcomes (Dionne et al., 2014). Understanding the field's evolution - how leadership conceptualization and related outcomes differ in time - can provide important information and might help spark important conversations between various leadership invisible colleges, and might ultimately result in important future research agendas for the leadership field.

Field advancements are often driven by research in small invisible colleges of scholars who drive the field's “intellectual development, by setting research agendas and conferring 
reputation" (Vogel, 2012, p. 1016). Such theoretical and methodological advancements, and consequent field revolutions, mainly happen when multiple levels of analysis are considered (e.g. Gould, 2002; Yammarino \& Dansereau, 2011). Examples of such revolutions are especially common in the natural sciences. For example, a well-known example is when researchers in physics acknowledged that matter in the form of atoms and molecules, consisting of protons, neutrons, electrons and various more basic particles and molecules, often disrupt each other's bond. The changes at the sub-molecular level changed the way we see and address matter (Gomes-Casseres, 1996). However, "revolutions" only represent a rather static snapshot of a field. They do not explain how these small invisible colleges evolved over time and how evolution might in time lead to drastically theoretical or methodological revolutions in the discipline (Vogel, 2012), like the conceptualization of leadership on different levels as a result of scientific communication, and the switch to different outcomes depending on what the leadership field was interested in.

To address time concerns, Vogel (2012) proposes an evolutionary framework of invisible colleges. He proposes seven patterns of how invisible colleges can evolve: college appearance is the emergence of a new college without predecessor in the same field, even though its foundations may be long-standing (e.g., LMX in late 1970s); college transformation is a gradual or sudden change of an existing college that may result in the formation of a new college (e.g., trust in 1990s into organizational justice in 2000s); college drift refers to a process by which parts of a college become incorporated into another, preexisting college (e.g., elements of group effectiveness in 1980s into transformational/transactional leadership research in 1990s); college differentiation describes a process by which a broadly defined college splits up into several new colleges with a higher degree of specialization (e.g., transformational/transactional leadership in 1990s into transformational, authentic, ethical, shared leadership in 2000s); college fusion happens when 
two or more previously indented colleges merge into a single college (e.g., colleges on governance, market orientation and firm capabilities in the 1990s merged into complexity/contextual research on leadership in 2000s); college implosion is when a college disappears without successor (e.g., self-management in 1980s or 1990s); and college revival describes a pattern when a college has temporarily disappeared and then reappears later on (e.g., procedural and interactional justice in 1980s into organizational justice research in 2000s).

The incorporation of levels-of-analysis considerations into theory building and empirical testing is a critical requisite for high quality research in the leadership field (Dionne et al., 2012). Given these peculiarities, a dynamic evolution perspective on the multi-level phenomena of the leadership field, especially for leadership occurrences and outcomes through invisible colleges and scientific communication, can provide important insight to move the field further. The next section outlines the methods we used to detect these invisible colleges and their pattern of evolution.

\section{Methods}

The methods used in this review stem from the bibliometric field - i.e. the statistical analysis of scholarly communication through publications (de Solla Price, 1965). Bibliometric analysis includes two categories, according to whether the focus is the activity indicator or the relationship indicator. The first category, citation analysis, provides data regarding the impact of the research effect. Co-citation analysis, the focus here, instead traces relationships and interactions between different researchers and can spawn outside a field of research, thus revealing the intellectual traditions within a field, and can trace field evolution over the course of time. 


\section{Document co-citation}

Co-citation analysis has been widely used in the past in various fields and contexts (see Fernandez-Alles \& Ramos-Rodriguez, 2009 for a brief overview). From the different options available to use for conducting the co-citation analysis (see Baker, 1990; Eom, 2008 for a review of these methods) we focus on one specific method - document co-citation analysis. A co-citation is defined as the frequency with which two documents are cited together in the literature (Small, 1973). In this sense you basically look at the dyad between two cited documents (see Figure 1) and how many times this dyad appears. Co-citation can be seen as intertextual relationships between scientific publications that are established by the referencing behavior of authors (Vogel \& Güttel, 2013). The basic assumption behind such behavior is that these relationships between the co-cited authors reflect some contextual similarities. A fundamental assumption of a co-citation analysis is that the more two items are cited together, the more likely it is that their content is related. To better understand this, think about the relationship between two friends: they stick together because they share some sort of similarities, maybe the both like basketball. As such it is very similar to a traditional "dyadic" approach often used in social network analysis and leadership research, where you assess relationships between any and all pairs in the sample. Documents are co-cited if they appear in the same document reference list, thus co-citation shows a similarity relationship between two cited publications (secondary document) that appear in the same citing document (primary document) (Figure 1).

\section{Insert Figure 1 about here}

Co-citation analysis carries three key aspects. First, co-citation analysis is a dynamic approach in that co-citation frequencies can increase over time, reshaping and remodeling the 
intellectual field. Second, because of the dynamics concept and accumulation of citations over time, the co-citation analysis can trace the intellectual roots of an academic discipline through the identification of its core works (Vogel \& Güttel, 2013). The older the document is, the longer it has been exposed to accumulate citations. Third, co-citation analysis provides a reliable indication of the impact of publications because citation counts reflect the resonance of a paper in the scholarly community (Verbeek, Debackere, Luwel, \& Zimmermann, 2002).

\section{Data}

Following standard procedures of co-citation analysis (for technical overviews see McCain, 1990, 1991; Zupic \& Čater, 2015), we started with the determination of our sample of primary papers. To identify papers that could potentially be used in our analysis we asked 17 well-published scholars in the field of leadership in a Delphi-type process to identify ten keywords that describe leadership outcomes and performance at one or more levels of analysis. All of them have published in LQ, while over half of them are or were members of the editorial board of LQ, and five of them serve or have served as senior editors or associate board members of LQ. We used this approach instead of others (using milestone key articles or already establish leadership approaches) as scholars deemed to be the most appropriate to capture the field as comprehensive as it can be (Zupic \& Čater, 2015). Further, the panel selected provided us with greater validity of search terms (Chabowski, Samiee, \& Hult, 2013), which cannot be obtained using other methods.

We then classified the keywords into broader groups in order to better capture the breadth of the field. For example, "motivation" and "follower motivation" were grouped under the "motivation" umbrella. We selected 12 groups that were composed of the highest number of components (Performance, Motivation, OCB (Organizational citizenship 
behavior), Citizenship behavior, Learning and Development, Satisfaction, Innovation and

Creativity, Commitment, Trust, Affect, Turnover) and used a Boolean “AND” to merge them with the root searching criteria - the keyword "leadership". This gave us 12 combinations for the search (for example, "Performance AND leadership"). We used these combinations in the ISI Web of Knowledge bibliographic database, identified to be the most reliable source of data (Bar-Ilan, 2008; Jacso, 2005, 2008).

We received 6,507 primary documents, which provided 178,854 unique secondary documents. A cutoff point, or a citation threshold, was applied to the reference list due to the high number of secondary documents (Fernandez-Alles \& Ramos-Rodriguez, 2009; Zupic \& Čater, 2015). The authors provide two explanations for why to choose a cutoff point. First, to limit the analyzed set to a manageable size to allow the software to compute a database that can be analyzed. Second, to ensure only cited publications that contain enough citation data for analysis are retained. If secondary documents are cited only rarely, their impact on the results will be trivial at the expense of more computational power.

Our cutoff point was decided after a series of iterations. We started from a threshold of 3, which provided 24,013 secondary articles. Such database in the later steps was too big to be successfully analyzed. We ran a series of trial-and-error attempts to find the best balance between clear comprehensive representation of the leadership field results and computational power used to further analyze the data. In the end we limited our analysis to 4,920 secondary documents cited ten or more times by primary articles.

\section{Analysis}

Bibexcel (Persson, Danell, \& Schneider, 2009) provides us with an intermediate result of the co-citation analysis - an aggregated matrix which displays the co-occurrences of the references in their bibliographies. In the next step, instead of using this raw matrix for 
classical bibliometrical analysis using it for a principal component analysis and multidimensional scaling (McCain, 1990, 1991), we exported it into network software Pajek (Batagelj \& Mrvar, 1998). We used network analysis as it is more effective in dealing with big data sets, such as the one our bibliometric analysis built upon (Leydesdorff, 2001; White, 2003).

In Pajek, we conducted the final analysis with the island algorithm in order to analyze dense clustered networks and split them into more understandable and easily explainable key groups. An island (research also refers to it as a cluster or college) is defined as a maximal subnetwork of vertices connected directly or indirectly by lines with a value higher than the lines outside (De Nooy, Mrvar, \& Batagelj, 2011). In our case, islands represent clusters of connected secondary papers that have been cited together at least a certain amount of times. More specifically, the link between the nodes (or papers) depicts the number of cooccurrences in which these two papers appeared together. A more abstract way to describe the same phenomena would be to consider this number as the height of the island above sea level. The higher the number, the higher will the island emerge from its surroundings - the water surface. This algorithm has been successfully applied in document co-citation analysis (Batistič \& Kaše, 2015), thus suggesting its suitable applicability for such analyses.

To visualize our data, we combined the island algorithm results with two-mode networks, which integrate different levels of analysis. Network diagrams can represent college maps that have been drawn by field experts over time (Vogel, 2012). Such maps give the research greater flexibility and more explanatory power (Polites \& Watson, 2009) compared to methods used in the past, like multidimensional scaling (e.g. White \& McCain, 1998). This visualization allowed us to examine the pivotal role of leadership and the outcomes level of conceptualization for each college. The creation of networks that consist of two sets of nodes, and thus offers the possibility to simultaneously explore two levels of 
analysis and their relationship to each other, constitutes a methodological innovation in the bibliometrics field and has rarely been used (see Vogel, 2012 for an exception). In the present study in Figures 2 and 3, the set of boxes (nodes) comprises clusters (colleges) of secondary co-cited works identified through the island algorithm.

The set of circles comprises the level of analysis adopted from these clusters of secondary co-cited works. For this study, a level of analysis is seen as tied to a cluster of cocited documents if the respective cluster has been identified to carry a document with such level of analysis. This was achieved by coding all levels of analysis of the documents present in the cluster to five categories - individual, dyadic, group, organizational, and multilevel - a method similar to that proposed by Yammarino et al. (2005). For the purpose of this study we define a category as multi-level if leadership was conceptualized or analyzed (i.e., in theory or in measurement) at two or more levels, and the same is applied for the outcomes of the study. The three authors of this study coded each document. The consensus rate achieved between the authors was between 0.68 and 0.93 . Disagreements were solved through discussion among the coders.

\section{Results}

We present the results split into three decades: 1980s, 1990s and 2000s up to 2013. Defining the timeframes is not yet a widely agreed step of the co-citation methodology (Zupic \& Čater, 2015). We based our decision to use 1980s as the first decade on two arguments: First, theoretically we identified from a multi-level review (Dionne et al., 2014) that around the start of 1980ies researchers increasingly expressed an unease about the conceptual and methodological approach to multi-level issues in leadership. Around the same time, Dansereau, Alutto and Yammarino (1984) developed a first comprehensive framework to address these issues. Therefore, we believe 1980 can form a quasi-baseline from which to 
explore the evolution of the multi-level approach in leadership. Second, as an emerging pattern, most bibliometric studies in other fields used similar timeframes, e.g., for management and organizational studies (Vogel, 2012), organizational socialization (Batistič \& Kaše, 2015), strategic management (Nerur, Rasheed, \& Natarajan, 2008). We chose 2013 as the last included year based on suggestions that documents need to be exposed to the field for a certain period of time in order to accumulate citations and impact the literature in the subject area (Fernandez-Alles \& Ramos-Rodriguez, 2009; Vogel \& Güttel, 2013).

The identified networks suggest that the field is not strictly segmented into welldefined and long-lasting research schools, but involves an interconnected, nested and lively socio-cognitive structure that consists of dynamic informal colleges. Since the aim is to detect colleges and their connections to the multi-level phenomena over time rather than to elaborate on them, the outline of the core groups merely serves to provide an interpretation of the extracted factors. Each factor is, of course, far more complex and has a richer tradition than its brief description suggests.

\section{The 1980s}

Table 1 shows the college map of the 1980s. The most prominent island, composed of 18 colleges, is Transformational and transactional leadership. Outstanding writings in this cluster mainly emerged from the work of Bass (1985) that launched the concept of transformational leadership, and from Conger and Kanungo (1987), dealing with a model linking organizational context and charismatic leadership. Publications assigned to this college are primarily concerned with seminal conceptualization of leadership theories in general, dealing specifically with two of its facets - transformational and transactional, and the emergence of charismatic leadership (Bennis \& Nanus, 1985). The second most important cluster is that of Agency and governance. This cluster mostly focuses on the organizational 
context and explores issues like boards of directors, separation of ownership and control, from a more economic perspective (Fama \& Jensen, 1983; Zahra \& Pearce, 1989). The label Competitive advantage was chosen for the next college because it strongly refers to work on competitive advantages of the firm from Porter (Porter, 1980). The college is committed to the assumption that firms use three generic strategies to create a defensible position and outperform competitors in a given industry; this assumption is refined and empirically tested by other members of this cluster (Dess \& Davis, 1984). A short description of other research themes can be find in Table 1 .

Insert Table 1 about here

Next, we explore how the colleges are connected to the conceptualization of leadership at different levels. We found that none of them conceptualized leadership as a multi-level phenomenon. The results show that the predominant conceptualization of leadership can be found at the individual and organizational level in this decade, with 13 and 9 papers respectively. In the first case, the individual level is strongly connected with the Transformational and transactional leadership island, whereas the organizational conceptualization of leadership can be seen mostly in the Agency and governance and Competitive advantage clusters. The group and dyadic conceptualizations of leadership appear to be less prominent, representing smaller colleges. For instance, group conceptualization is connected with Group effectiveness, Social identity and categorization, and Transformational and transactional leadership. Whereas the dyadic conceptualization informs the research in the LMX (leader-member exchange process), Agency and governance, and Processual and interactional justice clusters. Table 1 shows detailed results. 
When looking at the leadership outcomes (i.e. consequences of leadership phenomena) level of the colleges, we can see from Table 1 that most research has been done with individual or multi-level outcomes. Transformational and transactional leadership as the dominant college looked most at the individual level, followed by multi-level and organizational. Yet again we can see that multi-level outcomes are mostly connected with small clusters like Group effectiveness, Social identity and categorization and Processual and interactional justice. Organizational outcomes were also explored by the more "macro" clusters: Agency and governance and Competitive advantage. Dyadic outcomes were identified mostly within the $L M X$ cluster, whereas the only college looking at the group level outcome was, not surprisingly, Group effectiveness.

\section{The 1990s}

In the 1990s the leadership field seems to become more compact based on the number of colleges identified; more papers appear in a relatively smaller number of colleges. Overall eight colleagues can be identified, yet the number of document co-citations present rose to 54. Still, the most central and important cluster remains Transformational and transactional leadership, covering an extensive body of research dealing with transformational and transactional leadership. First meta-analyses emerged dealing with general effectiveness of such facets (Lowe, Kroeck, \& Sivasubramaniam, 1996) and researchers are still interested in the role of charisma in the transformational facet (Conger \& Kanungo, 1998; Shamir, House, \& Arthur, 1993). The second core college is Firm capabilities and knowledge. Although it is the largest cluster in the field, it is not the most central as it probably deals with issues less directly related to the notion of leadership. It explores competitive advantage issues of firms and includes, but is not limited to, seminal work about the resource-based view (Barney, 1991) and the role of knowledge as one of the key building mechanisms to gain competitive 
advantage (Grant, 1996). Similar issues are explored in the next cluster, named Creativity. It is concern with which factors can lead to greater creativity. Some of them are related to supportive or controlling supervision (Oldham \& Cummings, 1996), while others also take into account dyads and personal characteristics (Tierney, Farmer, \& Graen, 1999). As in the first decade, a short description of the research themes of other colleges can be found in Table 2.

Insert Table 2 about here

In the 1990s, conceptually, for the first time the conceptualization of leadership seems to be defined as multi-level, i.e. being conceptualized theoretically and/or operationalized empirically at multiple levels simultaneously. Interestingly, such conceptualization comes mostly from small clusters like Rater agreement and Creativity. Results show that the two most important colleges take only a partially multi-level conceptualization of leadership; in the Transformational and transactional leadership cluster only 2, and in the Firm capabilities and knowledge only three documents see leadership spawn over various levels. Beside the multi-level conceptualization with 12 documents, the most important conceptualization seems to be the organizational one, with 15 documents. Almost the majority (six of them) are coming from the Firm capabilities and knowledge cluster, followed by the Board composition and performance, with four. Individual level of conceptualization is like the multi-level, having 12 documents, mostly coming from the Transformational and transactional leadership, Creativity and Emotional intelligence clusters. Dyadic and group conceptualizations seem to lose momentum as such conceptualization is used less in the 1990s, compared to the 1980s. 
For the outcomes of the leadership field, the most studied consequences are at the individual level, with 17 documents, most of which come from the Transformational and transactional leadership, Creativity and Emotional intelligence clusters. Multi-level outcomes have been the focus mostly of the main colleges of Transformational and transactional leadership, Creativity and the small cluster of Trust. Group and dyadic outcomes are very rare and only researched by the main cluster and Trust. Interestingly, organizational outcomes, with 16 documents linked to them, seem to be a separate network, only linked by three "macro" themed colleges, among which Firm capabilities and knowledge provides nine, Market orientation provides three, and Board composition and performance provides four.

\section{The 2000s}

In the most recent of the three decades covered in this study, the leadership topography appears to have undergone considerable changes compared to the 1990s, as only seven colleges of quite different topic domains appear. The field's main college from 1980s seems to have been polarized to the Transformational leadership factually becoming the most important cluster in the 1990s. The most prominent role of the college is taken by metaanalysis still looking at transformational and transactional facets (Bass, Avolio, Jung, \& Berson, 2003), and innovative designs, dealing with time issues and experiments to explore the effect of predominantly transformational leadership on followers (Bono \& Judge, 2003; Dvir, Eden, Avolio, \& Shamir, 2002). A growing trend appears to influence research in emotions and emotional intelligence as the Emotions and emotional intelligence cluster is the second most important. Research about emotions in leadership undertake exploration of feelings (moods and emotions) and how they can influence the leadership process. It is proposed that emotional intelligence, the ability to understand and also manage moods and 
emotions can enhance leadership in organizations (George, 2000), and that emotion contagion can have a prominent role in such relationships (Sy, Côté, \& Saavedra, 2005). The third largest research area represents Authentic leadership. This cluster explores and tries to differentiate authentic leadership from other facets. It provides definition (being true to oneself) and empirical testing of this newly conceptualized facet of the leadership process and its effects on effectiveness (Avolio \& Gardner, 2005; Walumbwa, Avolio, Gardner, Wernsing, \& Peterson, 2008). Other clusters are explained more in detail in Table 3.

Insert Table 3 about here

When looking at the conceptualization of leadership field in the 2000s we see that multi-level is the most important level for the first time. Yet again most of the multi-level conceptualization comes from smaller clusters, like Emotions and emotional intelligence and Shared leadership (respectively with five and four documents) and Complexity, context and leadership. Surprisingly, two out of the three most important colleges conceptualized leadership in mostly different ways. Transformational leadership seems to conceptualize leadership predominantly as individual and group phenomena, whereas Authentic leadership investigates mostly at the individual level. Shared leadership also sees leadership as a group process, besides the multi-level one, with three documents connected to it. Organizational and dyadic conceptualizations are becoming less important. See Figure 2 for full results.

Insert Figure 2 about here

Finally, for the outcomes of leadership colleges, most consequences are studied at the individual level. These outcomes are the most important for the Emotions and emotional 
intelligence, Authentic leadership, and Transformational leadership. Multi-level outcomes are driven by research in the Emotions and emotional intelligence and Complexity, context and leadership clusters. Dyadic outcomes are losing momentum with only one research coming from Emotions and emotional intelligence, whereas group level outcomes were studied five times, predominantly from the Shared leadership perspective. Organizational outcomes were explored only once, again from the Shared leadership college. Overall results can be seen in Figure 3.

\section{Insert Figure 3 about here}

\section{Patterns of the evolution of leadership colleges' multi-level conceptualization}

The results of the network analysis presented in the previous section surfaced the nested, complex and multi-layered structure of multi-level conceptualization within the leadership field. In sum, 24 different colleges were identified and related to the level of analysis for leadership conceptualization and leadership outcomes. Comparing the networks across the decades confirms that colleges in fragmented clusters are not static but dynamic entities that evolve over time. In this section we present the evolutionary patterns of change across the entire time span in the leadership fields related to different conceptualizations of the leadership process. We use an evolutionary framework proposed by Vogel (2012) and used in other fields like organizational socialization (Batistič \& Kaše, 2015). The main evolution path in the 1980s and 1990s showed a move from the centrality of the Transformational and transactional leadership to a more Transformational leadership research in the 2000s. To a large extent, this line of research remains at the individual level, thus not embracing a multi-level logic to its full extent. Results are presented in Figure 4. 
Insert Figure 4 about here

College appearance is a materialization of a new college without predecessor, even though its foundations may be long-standing. The emergence of new colleges is a frequent process in the leadership field. For example, in the 1990s two new colleges appeared: Creativity and Emotional intelligence. This diversification might be enhanced by growing popularity of research specifically focused on leadership and increased journal publishing of leadership research (e.g. launch of new journals like The Leadership Quarterly). These appearances can be tracked to other fields that acknowledge the importance of a "leader" for a process studied by the college, for instance for Creativity. The connection of the leadership field with Emotional intelligence seems to be more indirect as its roots can be tracked to a more psychological perspective. Outstanding publications in such clusters contributed and promoted further exploration of such phenomena in regards to leadership process (Mayer \& Salovey, 1997; Oldham \& Cummings, 1996). With regard to the occurrence and outcomes of leadership, both colleges seem to focus on individuals concerning the level of analysis, and this individual, non-multi-level focus seems to represent the typical pattern for college appearance in the leadership field.

College transformation is a slow or sudden change of an existing college, which in many cases can result in the formation of a new college. As noted by Vogel (2012), to some extent this evolutionary pattern applies to all colleges as they, to a certain degree, always change over time. For example, the main evolutionary path of the leadership field can be seen as a college transformation; it started in the 1980s and 1990s with Transformational and transactional leadership. Even if the college name representing the main research theme is the same, it should be noted that the respective cluster underwent thematic changes which 
culminated in the 2000s in a transformation to Transformational leadership. This showed a decreasing interest in transactional leadership and greater emphasis on the transformational facet (Bono \& Judge, 2003). Another example of an evolutionary path is the change of theme and leadership conceptualization in the leader-member exchange process ( $L M X)$. In the 1990s, the predominant leadership conceptualization of LMX from the 1980s changed focus and started to explore trust (Trust). In the 2000s we see a movement from trust-based research to organizational justice (Organizational justice). This movement shows a conceptualization of leadership with two different foci -individual and multi-level. Furthermore, our results show that most college transformations changed the conceptualization of leadership towards a more multi-level approach. This might suggest that college transformation is closely related with novel conceptualization of core phenomena in order to move research forward.

College drift refers to a process by which parts of a college become incorporated into another, pre-existing college (Vogel, 2012). While there is a degree of constant mobility within the fragmented leadership colleges, sometimes a whole cluster of significant documents changes its home college. One example of such drift can be seen in the Group effectiveness college in the 1980s as it become incorporated into the main Transformational and transactional leadership college. Most of the scholarly texts in the Transformational and transactional leadership college are in some way or other exploring how these two facets of leadership are influencing and impacting team performance (e.g. Podsakoff, MacKenzie, Moorman, \& Fetter, 1990). A consequence of this shift was that group or team effectiveness, and performance in a broader sense, became one important sub-topic of the transformational and transactional leadership debate (Lowe et al., 1996). Our results further show that if college drift is happening between a strong and prominent college and a peripheral one, in 
most cases the level of analyses that will emerge will be driven by the stronger college, such as transformational leadership.

College differentiation describes a process by which an overarching, defined college splits up into several new colleges, each with a more specialized focus. It indicates a pattern of divergent evolution. One of the most obvious example is, in the 2000s, the differentiation of the Transformational and transactional leadership cluster compared with the 1990s. Sharing similar theoretical foundations deriving from transformational, transactional and charismatic leadership in the 2000 s we see three new colleges which address the inner meaning of positive self (Authentic leadership), explain vertical and horizontal leadership processes (Shared leadership) and deal with ethical issues of the leadership process (Ethical leadership). This example suggests that the differentiation of a college is often related to its migration to and refinement through a consolidation of specialized publication outlets (here, The Leadership Quarterly) and accompanied by growth in the number of publications. Regarding the level of analysis, the Transformational leadership college remained an individual-level cluster similar to the new college of Authentic leadership. Shared leadership instead showed a focus on multi-level and Ethical leadership approached individual and multi-level analysis.

College fusion happens when two or more previously independent colleges merge into a single college. An example of this pattern of convergent evolution in the leadership field can be seen in the integration of Board composition and performance, Market orientation, and Firm capabilities and knowledge from the 1990s into a new college - Complexity, context and leadership, in the 2000s. As the later college explores various multi-level theoretical/conceptual issues of leadership, the aggregation of these three clusters into a new one dealing with context is not surprising. This context is composed of topics ranging from the board of directors and their goals to firm competitive advantages in various forms (like 
knowledge) (Osborn, Hunt, \& Jauch, 2002). This suggests that fusion is likely to happen if the merging colleges are, to a certain extent, related and predisposed towards each other's theories (and methods). Our results further suggest that such college fusion can also change the focus of the level conceptualization of the foci phenomena. Thus leadership in the new college of Complexity, context, and leadership is a multi-level phenomenon. Perhaps this can be explained by the fact that previous clusters already tackle leadership at different organizational levels (boards, business functions etc.), and in order to merge into a new college it is apparent that such a different conceptualization has been taken into account, thus making this new college truly multi-level.

College implosion is when a college disappears without successor. The disappearance of present colleges is a common phenomenon in the evolution of a field (Batistič \& Kaše, 2015; Vogel, 2012). It was suggested that this mortality is particularly high among more peripheral colleges and in some cases, even core colleges are not immune. In our case, the 1990s showed disappearances of Self-management and Processual and interactional justice, among the others. In the 2000s Creativity, one of the main cluster of the 1990s, did not emerge. Yet it needs to be noted that colleges are unlikely to dissipate completely within a short time. Residual parts of creativity can be still traced in the Shared leadership cluster in the 2000s (e.g. Pearce, 2004). Thus, although in the 2000s Creativity no longer manifests as an independent college, it was not completely absent from the field either. In general, it seems that the majority of college implosions are happening with colleges that adopt a singlelevel leadership conceptualization, in particular, those who conceptualize leadership on the individual level. 


\section{Discussion}

The results of our three decades' bibliometric study have indicated that the multi-level aspect in leadership research is still fragmented. The identified sub-disciplines in leadership follow different evolutionary paths with respect to the multi-level approach. Our study explored the development of the multi-level nature of leadership conceptualization and leadership outcomes over three decades using Vogel's (2012) evolutionary framework. The results show firstly that the multi-level approach was mostly already introduced for the lens of leadership outcome in the 1980s. For example, in the main cluster of Transformational and transactional leadership in 1980s, 6 out of 18 papers already looked at multi-level outcomes. The theoretical conceptualizations of the leadership occurrence as a multi-level phenomenon appeared to gain ground later in the 2000s when 5 out of 7 clusters conceptualized leadership as multi-level phenomena.

Further, our document co-citation analysis surfaced invisible colleges and their dynamics across time - the informal groups structuring along the momentum in the field of leadership that use (or do not use) a multi-level approach. The evolutionary portrayal in Figure 4 summarizes the overall development. While we have shown that some colleges have imploded (e.g. Self-management and Social identity and categorization), our analysis shows that only particular, non-focal or even peripheral topics within the field, such as Shared leadership, Trust, Complexity, context and leadership and Emotions and emotional intelligence, embraced a multi-level approach for both of the studied perspectives of leadership conceptualizations, as well as the outcomes associated with leadership. This seems a promising way to carry the field forward. The multi-level thinking still seems to be a young and underdeveloped perspective in leadership, since most domains appear to be gaining momentum in the 2000's: collective/shared leadership, organizational justice and the 
complexity/contextual approach. Interestingly the emotional leadership/emotional intelligence stream of research appears to be more important for the leadership field than is usually predicted in the leadership review studies (DeChurch et al., 2010; Dionne et al., 2012; Dionne et al., 2014; Markham, 2010).

Other areas of leadership primarily focused either only on multi-level leadership conceptualizations (for example Emotions and emotional intelligence) or on a multi-level approach to leadership outcomes (for example, Shared leadership). Finally, some leadership colleges or sub-domains, which actually represent dominant colleges in the development of the field, seem to lag behind or largely neglect the application of a multi-level approach. In the most influential colleges of Transformational leadership research (none of the papers in the cluster conceptualize leadership as multi-level) or Authentic leadership (only 2 out of 6 papers conceptualize leadership as a multi-level phenomenon) multi-level studies are close to non-existing in the most significant studies in those subfields.

Our results are based on a bibliometric technique of document co-citation that tries to unfold relationships between different invisible colleges in a field based on citation patterns over time. The network diagrams, as outcomes of such analysis, represent a map that has been unconsciously "drawn" by leadership scholars. Comparing network diagrams can reveal various evolutionary patterns between different invisible colleges. To better explore such dynamics over time we used a typology proposed by Vogel (2012), who proposed seven different evolutionary paths between invisible colleges.

Based on this typology, we can infer that the multi-level approach in the leadership field, both in terms of conceptualizing the leadership phenomena that articles discuss and in terms of the outcomes of this phenomena, has emerged from the periphery mainly via college appearance and college differentiation. Overall, for the lens of the multi-level approach in 
leadership it seems those theories have immediately adopted a multi-level perspective at a high level of complexity and proficiency (for example, shared leadership).

\section{Contributions to leadership research and future directions}

The aims of the study were twofold: first, to expand our understanding about the underlying structure and evolution of multi-level phenomena in the leadership field by offering a comprehensive, inclusive and objective review study. Second, we aimed to build on this to theorize about the future evolution and research directions for multi-level research in leadership. The study's first contribution, building on bibliometrical analyses with cocitation techniques (Small, 1973), lies in presenting a more aerial view - an objective and non-pre-determined examination (Garfield, 1979; Zupic \& Čater, 2015) of the evolution of the multi-level lens in the leadership field - as one of the most promising avenues of leadership research. Co-citation techniques are more data-grounded and thus less biased as they allow us to include thousands of textual resources rather than those pre-selected by researchers with a focus on one specific theme or high-impact journal (or set of journals), while neglecting other topics and outlets from the outset.

We applied the co-citation analysis to all potentially relevant sources (accounting for an as-wide-as-possible range of sources and topics in the leadership field) and made decisions about inclusion or exclusion of key studies on objective criteria related to each document's influence (co-citations). This is why the findings of our study are likely to be less biased from the outset by the institutionalized sense-making of journals or specific clusters of authors. Our methodology allowed for even more appropriate theorizing because it let the structure and evolution emerge objectively from all sources contributing to the entire field of leadership. Nevertheless, our conclusions, using a bibliographic technique, generally support or align with those of Yammarino et al. (2005) and Dionne et al. (2014) who used essentially 
a qualitative/content coding technique. In that sense, there seems to be some convergent validity—different methods being applied in review studies — lead to similar conclusions. Studies-- although conducted differently--tend to find a similar pattern and show some overlaps in the findings that the state of multi-level leadership research seems fragmented. More than 10 years after the study of Yammarino et al. (2005), it is still in its "infancy", primarily based at the individual level; it should not be so after all this time, theoretical and methodological advancements. Relatedly, authors tend to avoid multi-level work because it's "too difficult"-another invalid excuse if one wants to enhance the science of a field like leadership.

As for existing bibliometric studies, our research expands Tseng et al.’s (2010) work, since their bibliometric analysis focused on leadership in general, but purposefully considered only two journals. The broad base of sources also allowed us to identify true peripheral colleges (such as Ethical leadership and Board composition and performance) and dominant colleges (such as Transformational leadership) in the development of multi-level theory in leadership. This is in contrast to most reviews that pursue a strategy around pre-determining the initial base of studies, which often focus on mainstream leadership outlets or leadership sub-disciplines, therefore not catching developments at the periphery of the domain.

The second contribution of this study is the expansion of the limited theorizing about the past and future evolution of multi-level development in leadership (Liden et al., 2008; Schriesheim et al., 2009; Taggar \& Ellis, 2007). In theory, the study of leadership, like several other research fields, faces challenges of innovation in central areas of knowledge because established norms and implicit rules may create processes of rigidity or inertia (Alexy, George, \& Salter, 2013; Blaikie, 2007). Those identified evolutionary patterns allowed us to make three sets of informed speculations (Vogel, 2012) about how the multilevel approach might further advance in the leadership field overall and about the future 
evolution of specific leadership sub-disciplines and sub-colleges -i.e. dominant (e.g. Transformational leadership), peripheral (e.g. Organizational justice) or emerging colleges (e.g. Emotional intelligence). Regarding the three sets of speculation about the future direction of the leadership field, we envisage: a) a move towards an overcoming of the apparent stagnation of the dominant domain; b) future trajectories for multi-level approaches in emerging leadership domains; and c) an evolution from two-level research to three or more-level, that is, truly multi-level studies.

\section{Future trajectories addressing the apparent stagnation of the dominant domain}

From an evolutionary and patterning perspective, our dynamic analysis sheds light on differences in multi-level uptake between core domains such as transformational leadership that show multi-level stagnation and peripheral fields with multi-level adoption, such as shared leadership. In line with previous reviews (e.g., Gardner, Lowe, Moss, Mahoney, \& Cogliser, 2010; Lowe \& Gardner, 2000), we found that the colleges of transactional and transformational leadership and later transformational leadership theories have been among the most popular approaches. However, this most dominant domain as well as two of the colleges (Authentic leadership and to an extent Ethical leadership) that have differentiated from this domain, seem to be slower or to completely neglect to embrace a multi-level approach. All three colleges continue to conduct research as mono-level studies at an individual level of analysis. This discovery corroborates Dionne et al.'s (2012) review that focused solely on transformational/charismatic leadership and found a majority of articles located at the individual level of analysis. And while some studies investigate the transformational leadership phenomenon at a higher level of analysis - e.g. transformational leadership climate (Menges, Walter, Vogel, \& Bruch, 2011), or leadership outcomes for 
teams and followers collectively (DeChurch et al., 2010) - these still manifest as predominantly mono-level approaches.

We draw on the emerging perspective that recognizes transformational leadership as a dual-level phenomenon involving a simultaneous focus on both the group as a whole and the individuals who comprise the group (Wang \& Howell, 2010; Wu, Tsui, \& Kinicki, 2010). To expand the extent of multi-level approaches to the dominant domain of transformational leadership, we propose three possible future pathways.

A first pathway could be based on college differentiation by which a college splits up into several new colleges with a higher degree of specialization. A new peripheral college can use its independence to detach from the mono-level research paradigm and innovate in multilevel research. Our findings show an example with the differentiation of the sub-discipline of Shared leadership from the dominant Transformational leadership. From the start, the domain of Shared leadership had more emphasis on a multi-level approach (e.g. Pearce, 2004; Pearce \& Sims Jr, 2002), and while it acts as a component of the main domain, it is specialized upon leadership that emanates from members of teams, and not simply from the appointed leader. It included a multi-level paradigm from the start, since this enables more accurate assessment of individual- and group-level variance attributed to shared leadership. Further, colleges that emerged from our analysis as candidates for a potential break-away from the mainstream of transformational leadership research, consist of a methodological component. For example, Dvir et al. (2002) already used a field experiment study to explore how transformational leadership can have a more positive impact on direct followers' development and on indirect followers' performance. Such studies provide valuable practical value and real-life conditions and expanding research in this regard can advance the field evolution even more by further specializing upon some of the critical issues and by incorporating more robust research designs. 
Two further pathways, via college drift or college fusion, might overcome the stagnation toward multi-level approaches in the dominant leadership discipline. For the pathway of college drifting, we propose, for instance, the college of Emotions and emotional intelligence as a potential informative peripheral domain. Parts of the functioning and explanatory mechanisms of transformational leadership build on emotion research (e.g. Ashkanasy \& Tse, 2000; Bass, 1985; McColl-Kennedy \& Anderson, 2002). Including emotion research with a higher emphasis on multi-level theory and analysis (e.g. Ashkanasy, 2003 ) in the investigation of the transformational leadership phenomenon and its outcomes (see for an example To, Herman, \& Ashkanasy, 2015) can thus help to create a knowledge spillover and as such inform multi-level research in the dominant domain.

A third potential pathway builds on college fusion by which two or more previously independent colleges merge into a single college. Our findings showed this to be a beneficial developmental pattern that led to the merged, multi-level college of Complexity, context and leadership. Following this example, some conceptual sections of the dominant domain of transformational leadership could connect with topics from the periphery, such as Complexity, context and leadership, and jointly develop common colleges. This could be done by considering studies of complex multi-level contexts of leadership, for instance of the interaction between team- or even organizational-level climate and transformational leadership (Charbonnier-Voirin, El Akremi, \& Vandenberghe, 2010; Eisenbeiss, van Knippenberg, \& Boerner, 2008) into a college exploring climates such as supportive climates enhancing transformational leadership effects. Another opportunity would be to embrace a contingency view of transformational leadership that would examine when this leadership type leads to beneficial outcomes depending on a complex set of multi-level joint influences, such as personality (Judge \& Bono, 2000), HR systems (Zhu, Chew, \& Spangler, 2005) or organizational culture (Jaskyte, 2004). Examining these boundary conditions for leadership 
emergence can create a new merged cluster with a multi-level approach emphasis at the outset.

\section{Future trajectories for multi-level approaches in emerging leadership domains}

Our study may also allow for informed speculation about multi-level considerations for emerging leadership domains that represent hidden colleges (Vogel, 2012). Some fields, such as spiritual leadership, followership or complexity leadership (Bryman, Collison, Grint, Jackson, \& Uhl-Bien, 2011; Gardner et al., 2010), do not even surface in our co-citation analysis, probably because their publications are predominantly from recent years, but these fields have gained some momentum and structure via substantial reviews in the leadership literature. Our dynamic developmental analysis precludes three probable developmental trajectories for emerging domains which we illustrate with followership theory (Uhl-Bien, Riggio, Lowe, \& Carsten, 2014) as an exemplary case, assuming followership advances towards college appearance in future co-citation analyses.

1) Adopting established paths of dominant domains. Followership theory could evolve along a similar path as the transformational leadership field, i.e. mainly focusing on group and individual levels of analysis. A recent review corroborates this positon in that its five organizing categories for followership theory fall into individual or dyadic level of analysis (Uhl-Bien et al., 2014), thus not harnessing the full range of possible multi-level theorizing.

2) Evolution as college fusion with existing colleges that share conceptual proximity. Followership could merge with current, conceptually related colleges, such as Shared leadership. The followership domain may experience spillover effects from those clusters regarding approaches to multi-level research and, within a merged college, fully adopt a multi-level paradigm for theoretical progress. 
3) College appearance as one of the main colleges with embedded multi-level theory.

With this trajectory, followership appears as a completely new 'big island' (college)

indicating intense application of multi-level approaches, which is similar to the appearance of the emotions field in the present analysis. In this case, scholars proactively embrace a multilevel lens and acknowledge that followership processes and followership outcomes, akin to leadership, are complex phenomena that are co-created or co-constructed in nature, and are nested in teams, networks and/or organizations (Lord, Brown, Harvey, \& Hall, 2001; Yammarino \& Dansereau, 2011) and as such simultaneously play out at various levels of analysis.

\section{Embracing a true 'multi' perspective in multi-level leadership research}

A final trajectory in multi-level leadership research refers to both emerging and dominant domains. Future research may progress towards a full multi-level character of leadership studies from the current state in the field of prevailing dual-level approaches that typically incorporate two levels of analysis, which we dubbed as micro multi-level and organizational multi-level lenses. Going into more depth into the content of particular islands or colleges that have adopted a multi-level approach in the present study, we can witness a division around the pattern of which multiple levels are considered. The majority of the studies that apply a multi-level approach (e.g. Černe, Jaklič, \& Škerlavaj, 2013; Hsiung, 2012; Olsson et al., 2012) combine individual- and team-level analyses (micro multi-level lens), yet tend to neglect incorporating higher levels, such as unit or organization. Our study also surfaces that multi-level leadership research, which incorporates organizational level phenomena, tends to include only the group level or similar (organizational multi-level lens). While several notable exceptions include studies such as Ruiz, Ruiz \& Martínez (2011), Liu, Liao \& Loi (2012) and Schaubroeck et al. (2012), this lacuna in the literature calls for further, 
more complex, 'true' multi-level studies (meso; Klein \& Kozlowski, 2000) that would combine several (at least three) levels of analyses, such as individual, group and organizational, and account for their theorizing simultaneously. The leadership phenomenon is, for instance, not only about dyadic interactions, but rather describes how teams function in the presence and interaction with the leader(s), and are further embedded in networks of additional interactions with colleagues and leaders of other (or hierarchically superior) leaders (DeRue, 2011; Dionne et al., 2014). Similarly, considering outcomes of leadership processes may typically impact the people involved (e.g. individual commitment), the proximate environment they operate in (e.g., team cohesion) and over time, in the case of senior/higher-up leadership relations, the norms, implicit rules or performance of an organization or division. Addressing these co-occurrences in more depth could be an ambition for all three - the existing dominant domain in leadership and the identified peripheral domains - where some of the abovementioned three-level exceptions have taken up and also hidden colleges of emerging leadership domains. They could, for instance, be further enriched by linking multi-level theory and empirical approach to that of social and organizational network studies (Carter, DeChurch, Braun, \& Contractor, 2015).

\section{Limitations and conclusions}

Bibliometric approaches to the study of invisible colleges have certain limitations, which further suggests that such studies need to be complemented with other review methods, such as meta-analyses and qualitative reviews. First, while the division in our study in to three decades allowed us to see significant changes, other choices (e.g., different staring keywords, derived from a different method) might have led to the detection of colleges that have remained invisible to this study, provided that the accumulated citations are worth being processed with bibliometric methods. Second, the quantitative approaches used in 
bibliometrics do not capture in what context and with what intention authors refer to other works (Zupic \& Čater, 2015). Citing behavior can be a result of various motivational mechanisms, such as self-legitimization strategies, micro-politics and criticisms. However, such intentional behavior turn out to be less important than reviewing earlier works (Bornmann \& Daniel, 2008). Third, the resolution of the applied bibliometric method depends on thresholds defined in the course of data reduction (Zupic \& Čater, 2015). Such technical decisions made by researchers could potentially alter smaller colleges, rather and the main clusters. In the case of our study, we broadly varied different thresholds without observing drastic changes in the network and composition structure of various colleges. To conclude, our network-island review study of the uptake of the multi-level approach in leadership (phenomena and outcomes) rooted in bibliometric co-citation analysis and the theoretical framework of invisible colleges, identified three avenues that can drive the field forward. These are: 1) overcoming the stagnation in dominant domains by college differentiation, drifting or fusion; 2) developmental trajectories for emerging domains and; 3) embracing a 'true' multi-level approach by bridging the micro-macro divide and accounting for three or more levels of analysis simultaneously. This may result in broader theoretical progress and a practical impact for the leadership field in the future. 


\section{References}

Alexy, O., George, G., \& Salter, A. (2013). Cui bono? The selective revealing of knowledge and its implications for innovative activity. Academy of Management Review, 38(2), 270-291.

Ashkanasy, N. M. (2003). Emotions in organizations: A multi-level perspective. In F. J. Yammarino \& F. Dansereau (Eds.), Multi-level issues in organizational behavior and strategy (pp. 9-54). Oxford, UK: JAI Press.

Ashkanasy, N. M., \& Tse, B. (2000). Transformational leadership as management of emotion: A conceptual review. In N. M. Ashkanasy, C. Härtel \& W. Zerbe (Eds.), Emotions in the workplace. Research, theory, and practice (pp. 221-235). Westport, CT: Quorum.

Atwater, L. E., \& Yammarino, F. J. (1992). Does self-other agreement on leadership perceptions moderate the validity of leadership and performance predictions? Personnel Psychology, 45(1), 141-164.

Avolio, B. J., \& Gardner, W. L. (2005). Authentic leadership development: Getting to the root of positive forms of leadership. The Leadership Quarterly, 16(3), 315-338.

Baker, D. R. (1990). Citation analysis: A methodological review. Social Work Research \& Abstracts, 26(3), 3-10.

Bamberger, P. (2008). Beyond contextualization: Using context theories to narrow the micromacro gap in management research. Academy of Management Journal, 51(5), 839846.

Bar-Ilan, J. (2008). Which h-index? - A comparison of WoS, Scopus and Google Scholar. Scientometrics, 74(2), 257-271.

Barney, J. B. (1991). Firm resources and sustained competitive advantage. Journal of Management, 17(1), 99-121.

Bass, B. M. (1985). Leadership and performance beyond expectations. New York: Free Press.

Bass, B. M., Avolio, B. J., Jung, D. I., \& Berson, Y. (2003). Predicting unit performance by assessing transformational and transactional leadership. Journal of Applied Psychology, 88(2), 207-218. doi: 10.1037/0021-9010.88.2.207

Batagelj, V., \& Mrvar, A. (1998). Pajek - A Program for Large Network Analysis. Connections, 21(2), 47-57.

Batistič, S., \& Kaše, R. (2015). The organizational socialization field fragmentation: a bibliometric review. Scientometrics, 104(1), 121-146. doi: 10.1007/s11192-015-15381

Bennis, W. G., \& Nanus, B. (1985). Leaders: The strategies for taking charge. New York: Harper \& Row.

Bies, R. J., \& Moag, J. S. (1986). Interactional justice: Communication criteria of fairness. In R. J. Lewicki, B. H. Sheppard \& M. Bazerman (Eds.), Research on negotiation in organizations (pp. 43-55). Greenwich, CT: JAI Press.

Blaikie, N. (2007). Approaches to social enquiry: Advancing knowledge. Cambridge, UK: Polity Press.

Bono, J. E., \& Judge, T. A. (2003). Self-Concordance at Work: Toward Understanding the Motivational Effects of Transformational Leaders. The Academy of Management Journal, 46(5), 554-571. 
Bornmann, L., \& Daniel, H.-D. (2008). What do citation counts measure? A review of studies on citing behavior. Journal of Documentation, 64(1), 45-80.

Brown, M. E., Treviño, L. K., \& Harrison, D. A. (2005). Ethical leadership: A social learning perspective for construct development and testing. Organizational Behavior and Human Decision Processes, 97(2), 117-134.

Bryman, A., Collison, D., Grint, K., Jackson, B., \& Uhl-Bien, M. (2011). The SAGE handbook of leadership: Sage Publications.

Carter, D. R., DeChurch, L. A., Braun, M. T., \& Contractor, N. S. (2015). Social network approaches to leadership: An integrative conceptual review. Journal of Applied Psychology, 100(3), 597-622. doi: 10.1037/a0038922

Černe, M., Jaklič, M., \& Škerlavaj, M. (2013). Authentic leadership, creativity, and innovation: A multilevel perspective. Leadership, 9(1), 63-85.

Chabowski, R. B., Samiee, S., \& Hult, M. G. T. (2013). A bibliometric analysis of the global branding literature and a research agenda. Journal of International Business Studies, 44(6), 622-634. doi: 10.1057/jibs.2013.20

Charbonnier-Voirin, A., El Akremi, A., \& Vandenberghe, C. (2010). A multilevel model of transformational leadership and adaptive performance and the moderating role of climate for innovation. Group \& Organization Management, 35(6), 699-726.

Chen, G., Mathieu, J. E., \& Bliese, P. D. (2004). A framework for conducting multilevel construct validation. In F. J. Yammarino \& F. Dansereau (Eds.), Research in multilevel issues: Multilevel issues in organizational behavior and processes (Vol. 3, pp. 273-303). Oxford, UK: Elsevier.

Colquitt, J. A., Conlon, D. E., Wesson, M. J., Porter, C. O. L. H., \& Ng, K. Y. (2001). Justice at the millennium: A meta-analytic review of 25 years of organizational justice research. Journal of Applied Psychology, 86(3), 425-445.

Conger, J. A., \& Kanungo, R. N. (1987). Toward a Behavioral Theory of Charismatic Leadership in Organizational Settings. The Academy of Management Review, 12(4), 637-647.

Conger, J. A., \& Kanungo, R. N. (1998). Charismatic leadership in organizations. Thousand Oaks, CA: Sage Publications.

Crane, D. (1972). Invisible Colleges: Diffusion of Knowledge in Scientific Communities. Chicago: University of Chicago Press.

De Nooy, W., Mrvar, A., \& Batagelj, V. (2011). Exploratory Social Network Analysis with Pajek (2nd ed.). Cambridge: Cambridge University Press.

de Solla Price, D. J. (1965). Networks of Scientific Papers Science, 149(3683), 510-515.

DeChurch, L. A., Hiller, N. J., Murase, T., Doty, D., \& Salas, E. (2010). Leadership across levels: Levels of leaders and their levels of impact. The Leadership Quarterly, 21(6), 1069-1085. doi: DOI: 10.1016/j.leaqua.2010.10.009

DeRue, D. S. (2011). Adaptive leadership theory: Leading and following as a complex adaptive process. Research in Organizational Behavior, 31(0), 125-150. doi: 10.1016/j.riob.2011.09.007

Dess, G. G., \& Davis, P. S. (1984). Porter's (1980) Generic Strategies as Determinants of Strategic Group Membership and Organizational Performance. The Academy of Management Journal, 27(3), 467-488.

Dienesch, R. M., \& Liden, R. C. (1986). Leader-Member Exchange Model of Leadership: A Critique and Further Development. The Academy of Management Review, 11(3), 618634.

Dinh, J. E., Lord, R. G., Gardner, W. L., Meuser, J. D., Liden, R. C., \& Hu, J. (2014). Leadership theory and research in the new millennium: Current theoretical trends and 
changing perspectives. The Leadership Quarterly, 25(1), 36-62. doi: http://dx.doi.org/10.1016/j.leaqua.2013.11.005

Dionne, S. D., Chun, J. U., Hao, C., Serban, A., Yammarino, F. J., \& Spangler, W. D. (2012). Article quality and publication impact via levels of analysis incorporation: An illustration with transformational/charismatic leadership. The Leadership Quarterly, 23(6), 1012-1042. doi: http://dx.doi.org/10.1016/j.leaqua.2012.10.003

Dionne, S. D., Gupta, A., Sotak, K. L., Shirreffs, K. A., Serban, A., Hao, C., . . Yammarino, F. J. (2014). A 25-year perspective on levels of analysis in leadership research. The Leadership Quarterly, 25(1), 6-35. doi: http://dx.doi.org/10.1016/j.leaqua.2013.11.002

Dvir, T., Eden, D., Avolio, B. J., \& Shamir, B. (2002). Impact of Transformational Leadership on Follower Development and Performance: A Field Experiment. The Academy of Management Journal, 45(4), 735-744.

Eggers, J., \& Kaplan, S. (2013). Cognition and capabilities: a multi-level perspective. The Academy of Management Annals, 7(1), 295-340.

Eisenbeiss, S. A., van Knippenberg, D., \& Boerner, S. (2008). Transformational leadership and team innovation: integrating team climate principles. Journal of Applied Psychology, 93(6), 1438-1446.

Eom, S. (2008). Author Cocitation Analysis: Quantitative Methods for Mapping the Intellectual Structure of an Academic Discipline. New York: Information Science Reference.

Fama, E. F., \& Jensen, M. C. (1983). Separation of Ownership and Control. Journal of Law and Economics, 26(2), 301-325.

Fernandez-Alles, M., \& Ramos-Rodriguez, A. (2009). Intellectual Structure of Human Resources Management Research: A Bibliometric Analysis of the Journal Human Resource Management, 1985-2005. Journal of the American Society for Information Science and Technology, 60(1), 161-175.

Finkelstein, S., \& D'Aveni, R. A. (1994). CEO Duality as a Double-Edged Sword: How Boards of Directors Balance Entrenchment Avoidance and Unity of Command. The Academy of Management Journal, 37(5), 1079-1108.

Gardner, W. L., Lowe, K. B., Moss, T. W., Mahoney, K. T., \& Cogliser, C. C. (2010). Scholarly leadership of the study of leadership: A review of The Leadership Quarterly's second decade, 2000-2009. The Leadership Quarterly, 21(6), 922-958. doi: 10.1016/j.leaqua.2010.10.003

Garfield, E. (1979). Is citation analysis a legitimate evaluation tool? Scientometrics, 1(4), 359-375. doi: 10.1007/BF02019306

George, J. M. (2000). Emotions and Leadership: The Role of Emotional Intelligence. Human Relations, 53(8), 1027-1055. doi: 10.1177/0018726700538001

Gladstein, D. L. (1984). Groups in Context: A Model of Task Group Effectiveness. Administrative Science Quarterly, 29(4), 499-517.

Gomes-Casseres, B. (1996). The alliance revolution : the new shape of business rivalry. London: Harvard University Press.

Gould, S. J. (2002). The structure of evolutionary theory. London: Belknap Press of Harvard University Press.

Grant, R. M. (1996). Toward a knowledge-based theory of the firm. Strategic Management Journal, 17(S2), 109-122.

Gupta, V. K., Huang, R., \& Niranjan, S. (2010). A longitudinal examination of the relationship between team leadership and performance. Journal of Leadership \& Organizational Studies, 17(4), 335-350. 
Hagstrom, W. O. (1965). The scientific community. New York: Basic Books.

Hernandez, M., Eberly, M. B., Avolio, B. J., \& Johnson, M. D. (2011). The loci and mechanisms of leadership: Exploring a more comprehensive view of leadership theory. The Leadership Quarterly, 22(6), 1165-1185. doi: http://dx.doi.org/10.1016/j.leaqua.2011.09.009

Hsiung, H.-H. (2012). Authentic leadership and employee voice behavior: A multi-level psychological process. Journal of Business Ethics, 107(3), 349-361.

Hunt, J. G., \& Dodge, G. E. (2000). Leadership déjà vu all over again. The Leadership Quarterly, 11(4), 435-458.

Hunter, S. T., Bedell-Avers, K. E., \& Mumford, M. D. (2007). The typical leadership study: Assumptions, implications, and potential remedies. The Leadership Quarterly, 18(5), 435-446.

Jacso, P. (2005). As we may search - Comparison of major features of the Web of Science, Scopus, and Google Scholar citation-based and citation-enhanced databases. Current Science, 89(9), 1537-1547.

Jacso, P. (2008). Google Scholar revisited. Online Information Review, 32(1), 102 - 114.

Jaskyte, K. (2004). Transformational leadership, organizational culture, and innovativeness in nonprofit organizations. Nonprofit Management and Leadership, 15(2), 153-168.

Jaworski, B. J., \& Kohli, A. K. (1993). Market orientation: Antecedents and consequences. Journal of Marketing, 57(3), 53-70.

Judge, T. A., \& Bono, J. E. (2000). Five-factor model of personality and transformational leadership. Journal of Applied Psychology, 85(5), 751-765.

Klein, K. J., \& Kozlowski, S. W. J. (2000). From micro to meso: Critical steps in conceptualizing and conducting multilevel research. Organizational Research Methods, 3(3), 211-236.

Kozlowski, S. W. J., \& Klein, K. J. (2000). A multilevel approach to theory and research in organizations: Contextual, temporal, and emergent processes. In K. J. Klein \& S. W. J. Kozlowski (Eds.), Multilevel theory, research, and methods in organizations: Foundations, extensions, and new directions (pp. 3-90). San Francisco, CA: JosseyBass.

Leydesdorff, L. (2001). The challenge of scientometrics: The development, measurement, and selforganization of scientific communications. Parkland: Universal Publications.

Liden, R. C., Wayne, S. J., Zhao, H., \& Henderson, D. (2008). Servant leadership: Development of a multidimensional measure and multi-level assessment. The Leadership Quarterly, 19(2), 161-177. doi: DOI: 10.1016/j.leaqua.2008.01.006

Liu, D., Liao, H., \& Loi, R. (2012). The dark side of leadership: A three-level investigation of the cascading effect of abusive supervision on employee creativity. Academy of Management Journal, 55(5), 1187-1212.

Lord, R. G., Brown, D. J., Harvey, J. L., \& Hall, R. J. (2001). Contextual constraints on prototype generation and their multilevel consequences for leadership perceptions. The Leadership Quarterly, 12(3), 311-338.

Lowe, K. B., \& Gardner, W. L. (2000). Ten years of The leadership quarterly: Contributions and challenges for the future. Leadership Quarterly, 11(4), 459-514.

Lowe, K. B., Kroeck, K. G., \& Sivasubramaniam, N. (1996). Effectiveness correlates of transformational and transactional leadership: A meta-analytic review of the mlq literature. The Leadership Quarterly, 7(3), 385-425.

Mabe, P. A., \& West, S. G. (1982). Validity of self-evaluation of ability: A review and metaanalysis. Journal of Applied Psychology, 67(3), 280-296. 
Manz, C. C. (1986). Self-Leadership: Toward an Expanded Theory of Self-Influence Processes in Organizations. The Academy of Management Review, 11(3), 585-600.

Markham, S. E. (2010). Leadership, levels of analysis, and déjà vu: Modest proposals for taxonomy and cladistics coupled with replication and visualization. The Leadership Quarterly, 21(6), 1121-1143. doi: DOI: 10.1016/j.leaqua.2010.10.011

Mathieu, J., \& Chen, G. (2011). The Etiology of the Multilevel Paradigm in Management Research. Journal of Management, 37(1), 395-403.

Mayer, J. D., \& Salovey, P. (1997). What is emotional intelligence? In P. Salovey \& D. Sluyter (Eds.), Emotional development and emotional intelligence: Implications for educators (pp. 3-31). New York: Basic Books.

McAllister, D. J. (1995). Affect- and Cognition-Based Trust as Foundations for Interpersonal Cooperation in Organizations. The Academy of Management Journal, 38(1), 24-59.

McCain, K. W. (1990). Mapping Authors in Intellectual Space: A Technical Overview. Journal of the American Society for Information Science (1986-1998), 41(6), 433443.

McCain, K. W. (1991). Mapping Economics through the Journal Literature: An Experiment in Journal Cocitation Analysis. Journal of the American Society for Information Science (1986-1998), 42(4), 290-296.

McColl-Kennedy, J. R., \& Anderson, R. D. (2002). Impact of leadership style and emotions on subordinate performance. The Leadership Quarterly, 13(5), 545-559.

Menges, J. I., Walter, F., Vogel, B., \& Bruch, H. (2011). Transformational leadership climate: Performance linkages, mechanisms, and boundary conditions at the organizational level. The Leadership Quarterly, 22(5), 893-909. doi: http://dx.doi.org/10.1016/j.leaqua.2011.07.010

Nerur, S. P., Rasheed, A. A., \& Natarajan, V. (2008). The intellectual structure of the strategic management field: an author co-citation analysis. Strategic Management Journal, 29(3), 319-336.

Oldham, G. R., \& Cummings, A. (1996). Employee Creativity: Personal and Contextual Factors at Work. The Academy of Management Journal, 39(3), 607-634.

Olsson, L., Hemlin, S., \& Pousette, A. (2012). A multi-level analysis of leader-member exchange and creative performance in research groups. The Leadership Quarterly, 23(3), 604-619.

Osborn, R. N., Hunt, J. G., \& Jauch, L. R. (2002). Toward a contextual theory of leadership. The Leadership Quarterly, 13(6), 797-837.

Pearce, C. L. (2004). The future of leadership: Combining vertical and shared leadership to transform knowledge work. The Academy of Management Executive, 18(1), 47-57.

Pearce, C. L., \& Sims Jr, H. P. (2002). Vertical versus shared leadership as predictors of the effectiveness of change management teams: An examination of aversive, directive, transactional, transformational, and empowering leader behaviors. Group Dynamics: Theory, Research, and Practice, 6(2), 172-197.

Persson, O., Danell, R., \& Schneider, J. W. (2009). How to use Bibexcel for various types of bibliometric analysis Celebrating Scholarly Communication Studies (Vol. 05-S): International Society for Scientometrics and Informetrics.

Podsakoff, P. M., MacKenzie, S. B., Moorman, R. H., \& Fetter, R. (1990). Transformational leader behaviors and their effects on followers' trust in leader, satisfaction, and organizational citizenship behaviors. The Leadership Quarterly, 1(2), 107-142. doi: http://dx.doi.org/10.1016/1048-9843(90)90009-7 
Polites, G., \& Watson, R. (2009). Using Social Network Analysis to Analyze Relationships Among IS Journals. Journal of the Association for Information Systems, 10(8), 595636.

Porter, M. E. (1980). Competitive strategy: Techniques for analyzing industries and competitors. New York: Free Press.

Ruiz, P., Ruiz, C., \& Martínez, R. (2011). Improving the "leader-follower" relationship: Top manager or supervisor? The ethical leadership trickle-down effect on follower job response. Journal of Business Ethics, 99(4), 587-608.

Schaubroeck, J. M., Hannah, S. T., Avolio, B. J., Kozlowski, S. W., Lord, R. G., Treviño, L. K., . . . Peng, A. C. (2012). Embedding ethical leadership within and across organization levels. Academy of Management Journal, 55(5), 1053-1078.

Schriesheim, C. A., Wu, J. B., \& Scandura, T. A. (2009). A meso measure? Examination of the levels of analysis of the Multifactor Leadership Questionnaire (MLQ). The Leadership Quarterly, 20(4), 604-616. doi: http://dx.doi.org/10.1016/j.leaqua.2009.04.005

Shamir, B., House, R. J., \& Arthur, M. B. (1993). The Motivational Effects of Charismatic Leadership: A Self-Concept Based Theory. Organization Science, 4(4), 577-594.

Small, H. (1973). Co-citation in the scientific literature: A new measure of the relationship between two documents. Journal of the American Society for Information Science, 24(4), 265-269.

Sy, T., Côté, S., \& Saavedra, R. (2005). The Contagious Leader: Impact of the Leader's Mood on the Mood of Group Members, Group Affective Tone, and Group Processes. 90, 295-305. doi: 10.1037/0021-9010.90.2.295

Taggar, S., \& Ellis, R. (2007). The role of leaders in shaping formal team norms. The Leadership Quarterly, 18(2), 105-120.

Tajfel, H., \& Turner, J. C. (1986). The Social Identity Theory of Intergroup Behavior. In S. Worchel \& W. G. Austin (Eds.), Psychology of Intergroup Relations (pp. 7-24). Chicago: Nelson-Hall.

Tierney, P., Farmer, S. M., \& Graen, G. B. (1999). An examination of leadership and employee creativity: The relevance of traits and relationships. Personnel Psychology, 52(3), 591-620.

To, M. L., Herman, H., \& Ashkanasy, N. M. (2015). A multilevel model of transformational leadership, affect, and creative process behavior in work teams. The Leadership Quarterly, 26(4), 543-556.

Tseng, H. C., Tung, H. L., \& Duan, C. H. (2010). Mapping the intellectual structure of modern leadership studies. Leadership \& Organization Development Journal, 31(1), 57-70. doi: doi:10.1108/01437731011010380

Uhl-Bien, M., Riggio, R. E., Lowe, K. B., \& Carsten, M. K. (2014). Followership theory: A review and research agenda. The Leadership Quarterly, 25(1), 83-104. doi: http://dx.doi.org/10.1016/j.leaqua.2013.11.007

Verbeek, A., Debackere, K., Luwel, M., \& Zimmermann, E. (2002). Measuring progress and evolution in science and technology - I: The multiple uses of bibliometric indicators. International Journal of Management Reviews, 4(2), 179.

Vogel, R. (2012). The Visible Colleges of Management and Organization Studies: A Bibliometric Analysis of Academic Journals. Organization Studies, 33(8), 1015-1043.

Vogel, R., \& Güttel, W. H. (2013). The Dynamic Capability View in Strategic Management: A Bibliometric Review. International Journal of Management Reviews, 15(4), 426446. 
Walumbwa, F. O., Avolio, B. J., Gardner, W. L., Wernsing, T. S., \& Peterson, S. J. (2008). Authentic Leadership: Development and Validation of a Theory-Based Measure. Journal of Management, 34(1), 89-126.

Wang, X.-H., \& Howell, J. M. (2010). Exploring the dual-level effects of transformational leadership on followers. Journal of Applied Psychology, 95(6), 1134-1144. doi: 10.1037/a0020754

White, H. D. (2003). Pathfinder networks and author cocitation analysis: A remapping of paradigmatic information scientists. Journal of the American Society for Information Science and Technology, 54(5), 423-434.

White, H. D., \& McCain, K. W. (1998). Visualizing a discipline: An author co-citation analysis of information science, 1972-1995. Journal of the American Society for Information Science, 49(4), 327-355.

Wu, J. B., Tsui, A. S., \& Kinicki, A. J. (2010). Consequences of Differentiated Leadership in Groups. Academy of Management Journal, 53(1), 90-106. doi: 10.5465/amj.2010.48037079

Yammarino, F. J., \& Dansereau, F. (2011). Multi-level issues in evolutionary theory, organization science, and leadership. The Leadership Quarterly, 22(6), 1042-1057.

Yammarino, F. J., Dionne, S. D., Uk Chun, J., \& Dansereau, F. (2005). Leadership and levels of analysis: A state-of-the-science review. The Leadership Quarterly, 16(6), 879-919. doi: http://dx.doi.org/10.1016/j.leaqua.2005.09.002

Zaccaro, S. J., Rittman, A. L., \& Marks, M. A. (2002). Team leadership. The Leadership Quarterly, 12(4), 451-483.

Zahra, S. A., \& Pearce, J. A. (1989). Boards of Directors and Corporate Financial Performance: A Review and Integrative Model. Journal of Management, 15(2), 291334.

Zhu, W., Chew, I. K., \& Spangler, W. D. (2005). CEO transformational leadership and organizational outcomes: The mediating role of human-capital-enhancing human resource management. The Leadership Quarterly, 16(1), 39-52.

Zupic, I., \& Čater, T. (2015). Bibliometric Methods in Management and Organization. Organizational Research Methods, 18(3), 429-472. doi: 10.1177/1094428114562629 
Figure 1 A document co-citation example

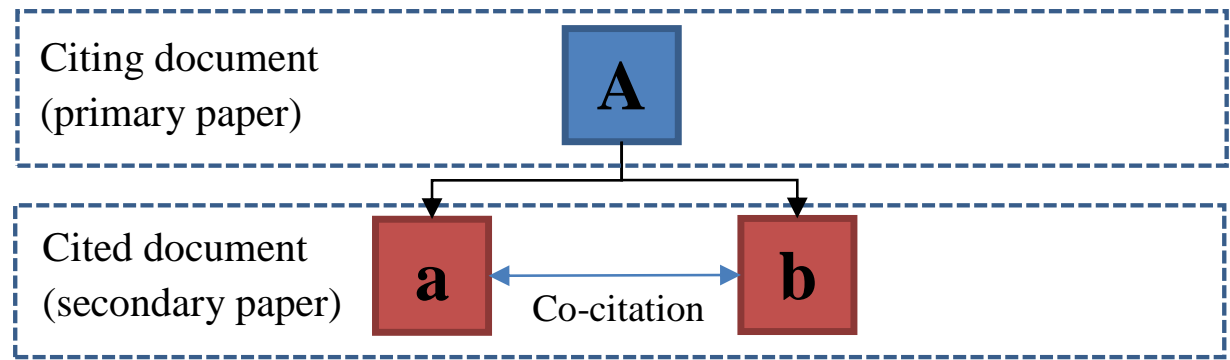


Figure 2 College map for leadership conceptualization at different levels, 2000-2009

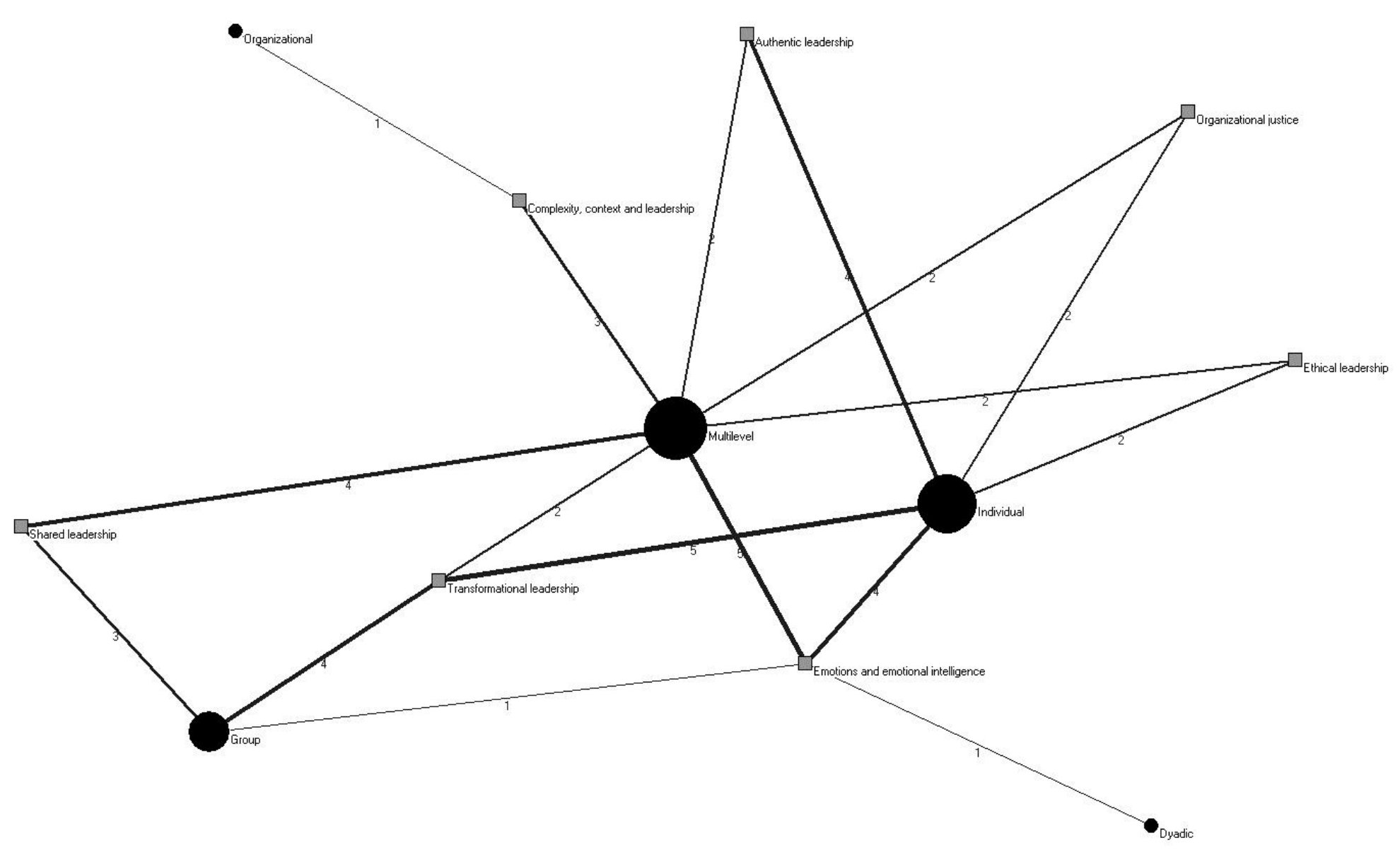

Circle size indicates the importance of the leadership level conceptualization. Line width with numbers indicates the frequency of appearance of article from a college at a given level. 
Figure 3 College map for leadership level outcomes at different levels, 2000-2009

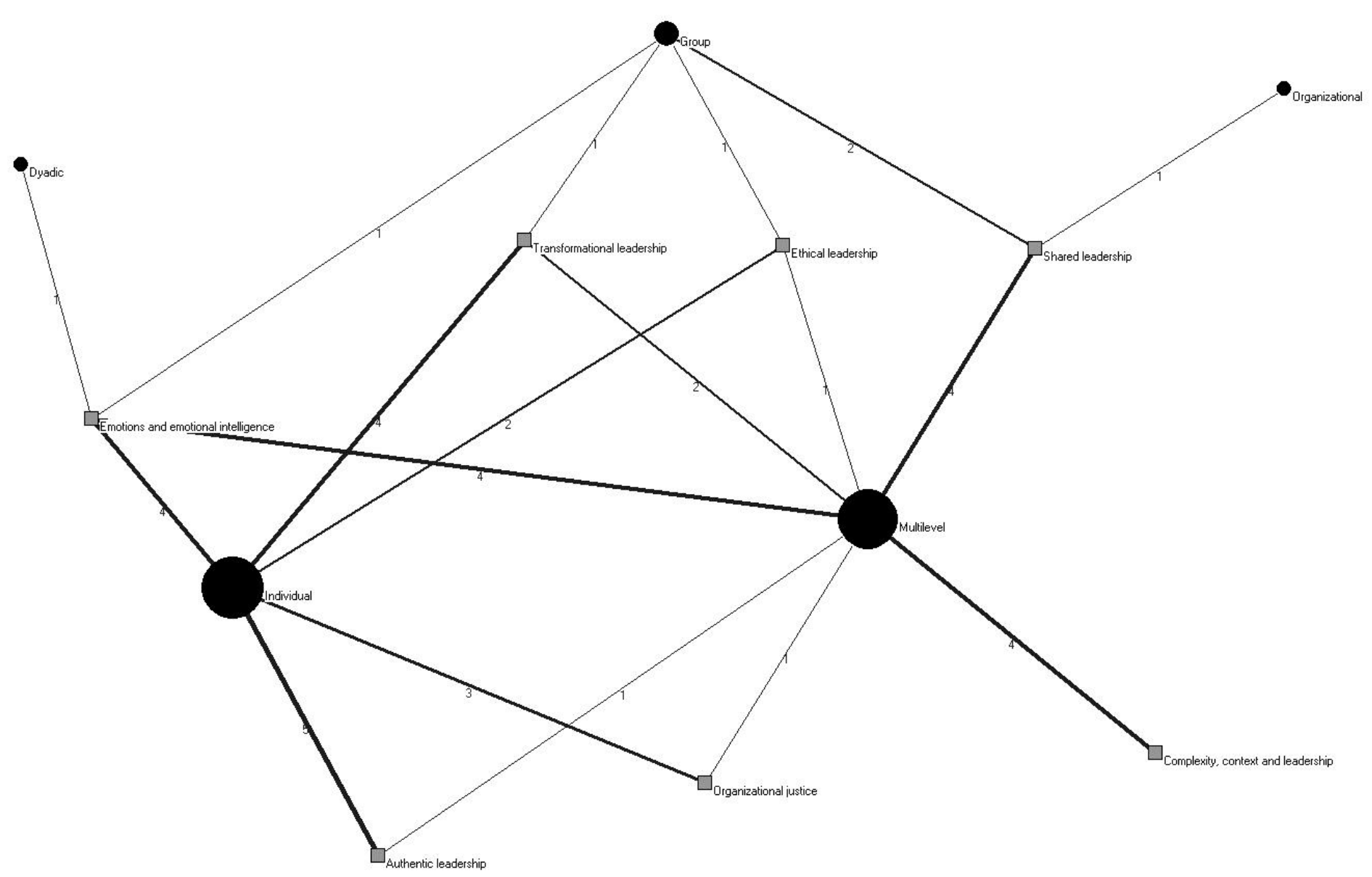

Circle size indicates the importance of the leadership level conceptualization. Line width with numbers indicates the frequency of appearance of article from a college at a given level. 
Figure 4 Development patterns of organizational leadership research

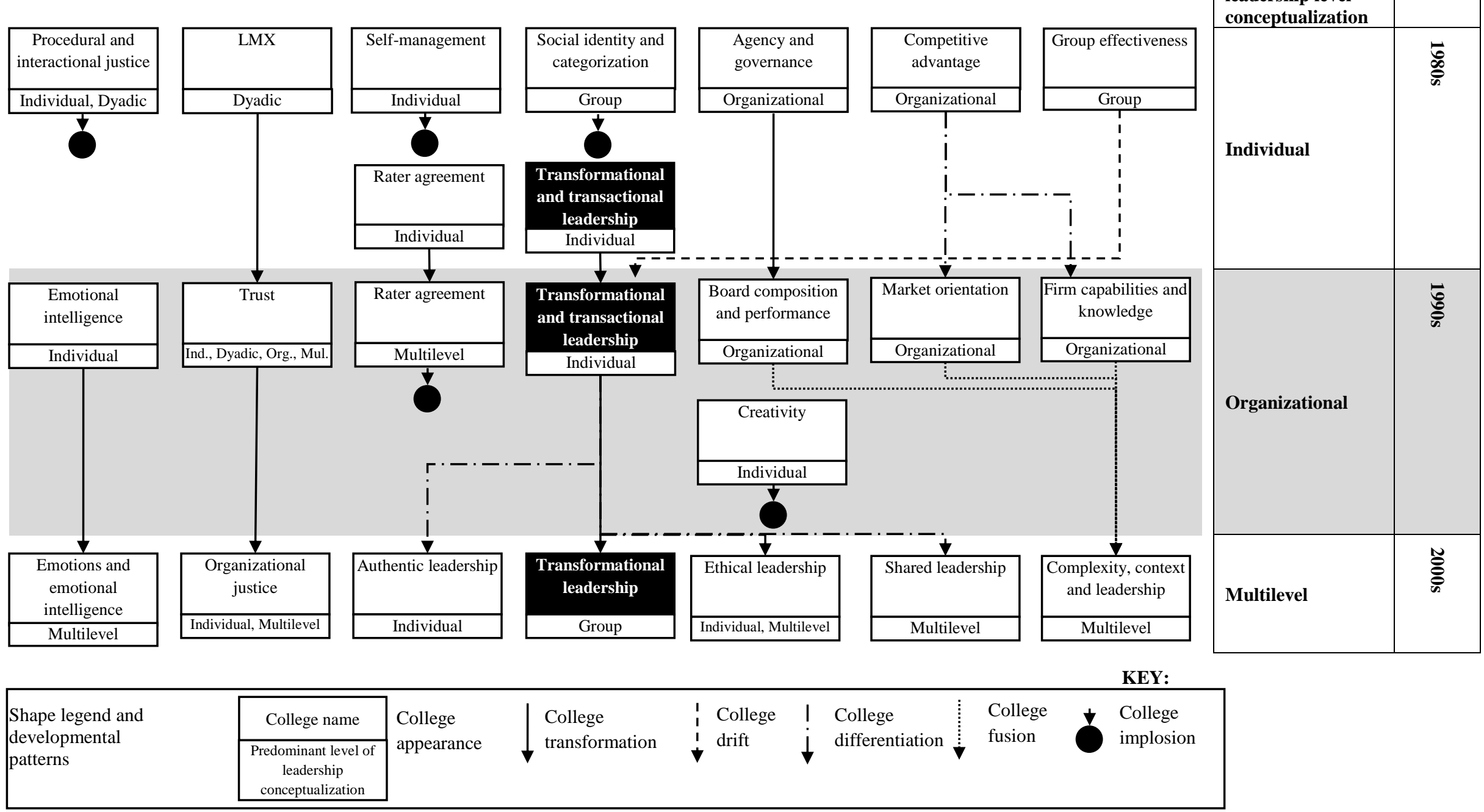


Table 1 Results of the bibliometric analysis for the leadership field in the 1980s

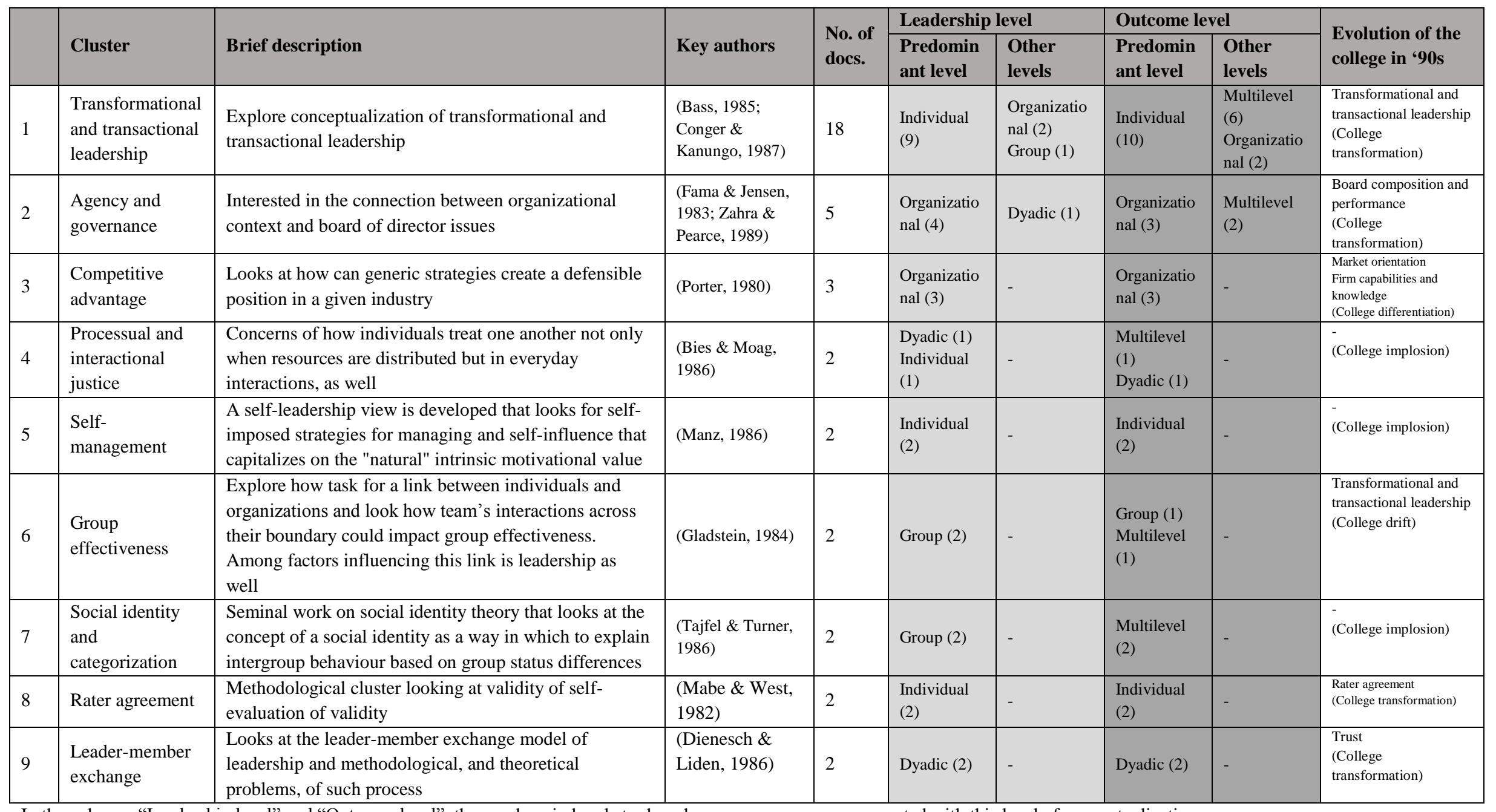

In the columns "Leadership level" and "Outcome level", the numbers in brackets show how many papers are connected with this level of conceptualization. 
Table 2 Results of the bibliometric analysis for the leadership field in the 1990s

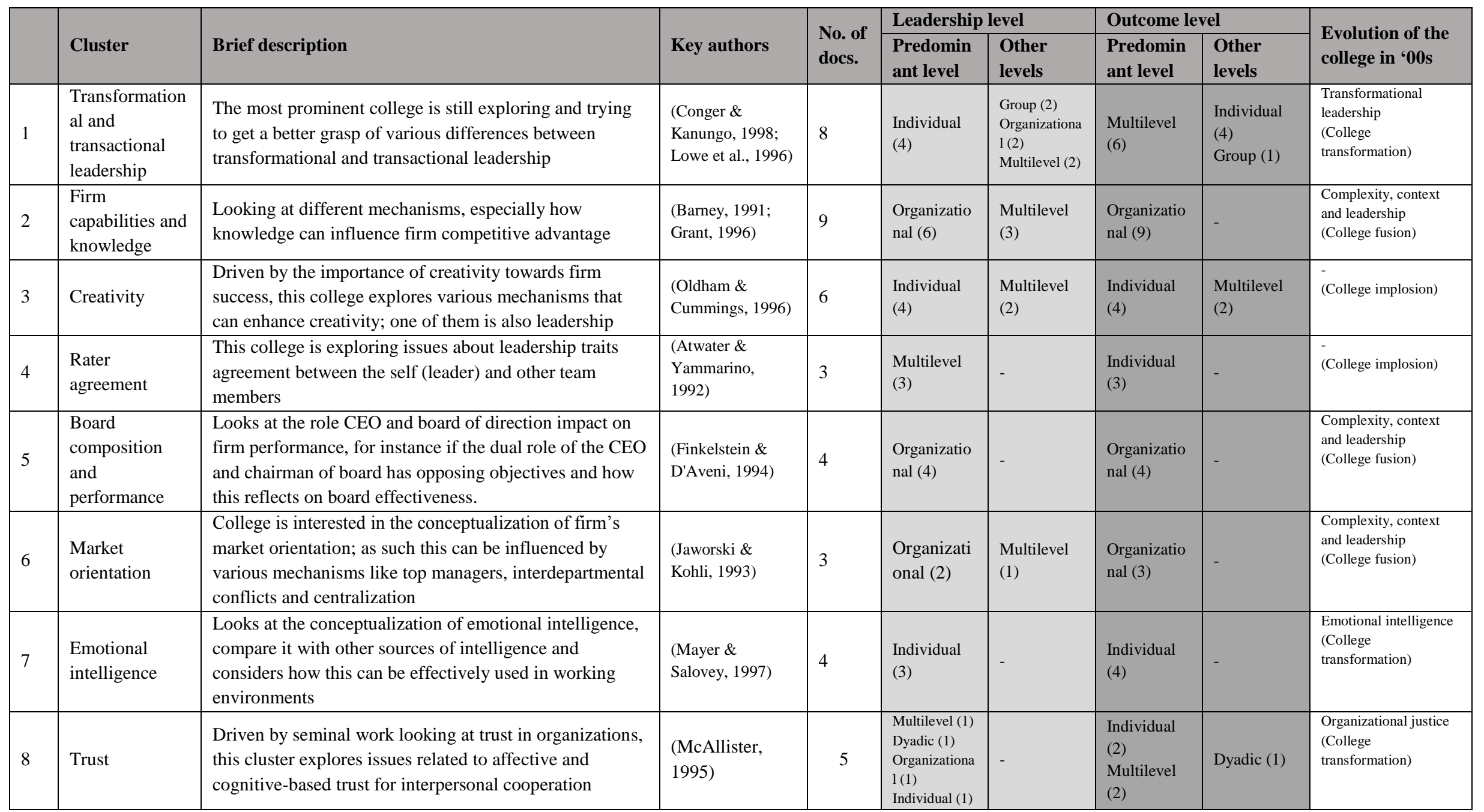

In the columns "Leadership level" and "Outcome level", the numbers in brackets show how many papers are connected with this level of conceptualization. 
Table 3 Results of the bibliometric analysis for the leadership field in the 2000s

\begin{tabular}{|c|c|c|c|c|c|c|c|c|}
\hline & \multirow[b]{2}{*}{ Cluster } & \multirow[b]{2}{*}{ Brief description } & \multirow[b]{2}{*}{ Key authors } & \multirow{2}{*}{$\begin{array}{l}\text { No. of } \\
\text { docs. }\end{array}$} & \multicolumn{2}{|c|}{ Leadership level } & \multicolumn{2}{|c|}{ Outcome level } \\
\hline & & & & & $\begin{array}{l}\text { Predomin } \\
\text { ant level }\end{array}$ & $\begin{array}{l}\text { Other } \\
\text { levels }\end{array}$ & $\begin{array}{l}\text { Predomin } \\
\text { ant level }\end{array}$ & $\begin{array}{l}\text { Other } \\
\text { levels }\end{array}$ \\
\hline 1 & $\begin{array}{l}\text { Transformation } \\
\text { al leadership }\end{array}$ & $\begin{array}{l}\text { The most prominent cluster looks at the influence of } \\
\text { transformational leadership on effectiveness. To achieve } \\
\text { this, research uses state of the art research design, like } \\
\text { experiments and accounting for time }\end{array}$ & $\begin{array}{l}\text { (Bass et al., 2003; } \\
\text { Bono \& Judge, } \\
\text { 2003) }\end{array}$ & 7 & Group (4) & $\begin{array}{l}\text { Individual } \\
\text { (3) }\end{array}$ & $\begin{array}{l}\text { Individual } \\
\text { (4) }\end{array}$ & $\begin{array}{l}\text { Multilevel } \\
\text { (2) } \\
\text { Group (1) }\end{array}$ \\
\hline 2 & $\begin{array}{l}\text { Emotions and } \\
\text { emotional } \\
\text { intelligence }\end{array}$ & $\begin{array}{l}\text { Explores the rationale that leaders' mood can be } \\
\text { transmitted to the mood of individual group members, } \\
\text { based on the mood contagion process }\end{array}$ & $\begin{array}{l}\text { (George, 2000; Sy } \\
\text { et al., 2005) }\end{array}$ & 10 & $\begin{array}{l}\text { Multilevel } \\
\text { (5) }\end{array}$ & $\begin{array}{l}\text { Individual } \\
\text { (3) } \\
\text { Group (1) } \\
\text { Dyadic (1) }\end{array}$ & $\begin{array}{l}\text { Multilevel } \\
\text { (4) } \\
\text { Individual } \\
\text { (4) }\end{array}$ & $\begin{array}{l}\text { Dyadic (1) } \\
\text { Group (1) }\end{array}$ \\
\hline 3 & $\begin{array}{l}\text { Authentic } \\
\text { leadership }\end{array}$ & $\begin{array}{l}\text { Leaders can build their legitimacy through honing } \\
\text { relationships with followers which value their input and } \\
\text { are built on an ethical foundation. Generally, authentic } \\
\text { leaders are positive people with truthful self-concepts and } \\
\text { who promote openness }\end{array}$ & $\begin{array}{l}\text { (Avolio \& } \\
\text { Gardner, 2005; } \\
\text { Walumbwa et al., } \\
\text { 2008) }\end{array}$ & 6 & $\begin{array}{l}\text { Individual } \\
\text { (4) }\end{array}$ & $\begin{array}{l}\text { Multilevel } \\
\text { (2) }\end{array}$ & $\begin{array}{l}\text { Individual } \\
\text { (5) }\end{array}$ & $\begin{array}{l}\text { Multilevel } \\
\text { (1) }\end{array}$ \\
\hline 4 & $\begin{array}{l}\text { Shared } \\
\text { leadership }\end{array}$ & $\begin{array}{l}\text { Driven by research into horizontal compared to vertical } \\
\text { leadership, this college explores the possibility that } \\
\text { shared leadership might also influence effectiveness }\end{array}$ & $\begin{array}{l}\text { (Pearce \& Sims Jr, } \\
\text { 2002) }\end{array}$ & 7 & $\begin{array}{l}\text { Multilevel } \\
\text { (4) }\end{array}$ & Group (3) & $\begin{array}{l}\text { Multilevel } \\
\text { (4) }\end{array}$ & $\begin{array}{l}\text { Group (2) } \\
\text { Organizatio } \\
\text { nal (1) }\end{array}$ \\
\hline 5 & $\begin{array}{l}\text { Ethical } \\
\text { leadership }\end{array}$ & $\begin{array}{l}\text { This college explores the notion that leaders should be a } \\
\text { key source of ethical guidance for employees. This } \\
\text { renewed guide research to explore theoretical and to } \\
\text { provide empirical evidence of ethical leadership }\end{array}$ & $\begin{array}{l}\text { (Brown, Treviño, } \\
\& \text { Harrison, 2005) }\end{array}$ & 4 & $\begin{array}{l}\text { Multilevel } \\
\text { (2) } \\
\text { Individual } \\
(2)\end{array}$ & - & $\begin{array}{l}\text { Individual } \\
\text { (2) }\end{array}$ & $\begin{array}{l}\text { Group (1) } \\
\text { Multilevel } \\
(1)\end{array}$ \\
\hline 6 & $\begin{array}{l}\text { Organizational } \\
\text { justice }\end{array}$ & $\begin{array}{l}\text { This research investigated whether procedural and } \\
\text { interactional justice affects work-related outcomes } \\
\text { through different social exchange relationships }\end{array}$ & $\begin{array}{l}\text { (Colquitt, Conlon, } \\
\text { Wesson, Porter, \& } \\
\mathrm{Ng}, 2001 \text { ) }\end{array}$ & 4 & $\begin{array}{l}\text { Multilevel } \\
\text { (2) } \\
\text { Individual } \\
\text { (2) }\end{array}$ & - & $\begin{array}{l}\text { Individual } \\
\text { (3) }\end{array}$ & $\begin{array}{l}\text { Multilevel } \\
\text { (1) }\end{array}$ \\
\hline 7 & $\begin{array}{l}\text { Complexity, } \\
\text { context and } \\
\text { leadership }\end{array}$ & $\begin{array}{l}\text { The focus of this cluster is to look beyond micro and } \\
\text { meso conceptualization of leadership and to include the } \\
\text { broader context }\end{array}$ & $\begin{array}{l}\text { (Osborn et al., } \\
\text { 2002) }\end{array}$ & 4 & $\begin{array}{l}\text { Multilevel } \\
\text { (3) }\end{array}$ & $\begin{array}{l}\text { Organizatio } \\
\text { nal (1) }\end{array}$ & $\begin{array}{l}\text { Multilevel } \\
\text { (4) }\end{array}$ & - \\
\hline
\end{tabular}

In the columns "Leadership level" and "Outcome level", the numbers in brackets show how many papers are connected with this level of conceptualization. 